\title{
Composition and sources of sedimentary organic matter in the deep eastern Mediterranean Sea
}

\author{
R. Pedrosa-Pàmies ${ }^{1,2}$, C. Parinos ${ }^{2}$, A. Sanchez-Vidal ${ }^{1}$, A. Gogou ${ }^{2}$, A. Calafat ${ }^{1}$, M. Canals ${ }^{1}$, I. Bouloubassi ${ }^{3}$, and \\ N. Lampadariou ${ }^{4}$ \\ ${ }^{1}$ GRC Geociències Marines, Departament d'Estratigrafia, Paleontologia i Geociències Marines, Universitat de Barcelona, \\ Barcelona, Catalonia, Spain \\ ${ }^{2}$ Hellenic Centre for Marine Research (HCMR), Institute of Oceanography, Anavyssos, Attiki, Greece \\ ${ }^{3}$ Laboratoire d'Océanographie et du Climat: Expérimentation et Approches Numériques (LOCEAN), CNRS - \\ Université Pierre et Marie Curie, Paris, France \\ ${ }^{4}$ Hellenic Centre for Marine Research (HCMR), Institute of Oceanography, Heraklion, Crete, Greece
}

Correspondence to: A. Sanchez-Vidal (anna.sanchez@ub.edu)

Received: 3 June 2015 - Published in Biogeosciences Discuss.: 3 July 2015

Revised: 20 November 2015 - Accepted: 28 November 2015 - Published: 16 December 2015

\begin{abstract}
Surface sediments collected from deep slopes and basins (1018-4087 $\mathrm{m}$ depth) of the oligotrophic eastern Mediterranean Sea have been analysed for bulk elemental and isotopic composition of organic carbon, total nitrogen and selected lipid biomarkers, jointly with grain size distribution and other geochemical proxies. The distribution and sources of sedimentary organic matter (OM) have been subsequently assessed and general environmental variables, such as water column depth and physical circulation patterns, have been examined as causative factors of deep-sea sediment characteristics. Lithogenic and biogenic carbonates are the dominant sedimentary fractions, accounting for up to 85.4 and $66.5 \%$ of the total weight respectively. The low $\mathrm{OC}$ and $\mathrm{TN}$ contents in the surface sediments of the study area, which ranged from 0.15 to $1.15 \%$ and 0.06 to $0.11 \%$ respectively, reflect the oligotrophic character of the eastern Mediterranean Sea. Both bulk and molecular organic tracers reflect a mixed contribution from autochthonous and allochthonous sources for the sedimentary OM, as indicated by relatively degraded marine $\mathrm{OM}$, terrestrial plant waxes and anthropogenic OM (e.g. degraded petroleum by-products) respectively. Wide regional variations have been observed amongst the studied proxies, which reflect the multiple factors controlling sedimentation in the deep eastern Mediterranean Sea. Our findings highlight the role of deep eastern Mediterranean basins as depocentres of organic-rich finegrained sediments (mean $5.4 \pm 2.4 \mu \mathrm{m}$ ), with OM accumula-
\end{abstract}

tion and burial being attributed to aggregation mechanisms and hydrodynamic sorting. A multi-proxy approach is applied aiming to investigate the biogeochemical composition of sediment samples, which sheds new light on the sources and transport mechanisms along with the impact of preservation vs. diagenetic processes on the composition of sedimentary OM in the deep basins of the oligotrophic eastern Mediterranean Sea.

\section{Introduction}

The burial of organic matter (OM) in marine sediments constitutes the main link between "active" pools of carbon in the oceans, atmosphere and landmasses and carbon pools that cycle on much longer, geological, timescales (Burdige, 2007). Therefore, investigating the processes that control the composition of sedimentary OM that is buried in deep-sea sediments is crucial for understanding carbon cycling on a global scale.

The deep sea receives inputs of organic particles from multiple sources, both autochthonous (e.g. biogenic particulate matter from primary production in ocean surface waters) and allochthonous (i.e. land-sourced OM from soils, plant debris, riverine phytoplankton and man-made compounds transported by runoff and atmospheric deposition into the marine domain) (Bouloubassi et al., 1997; Durrieu 


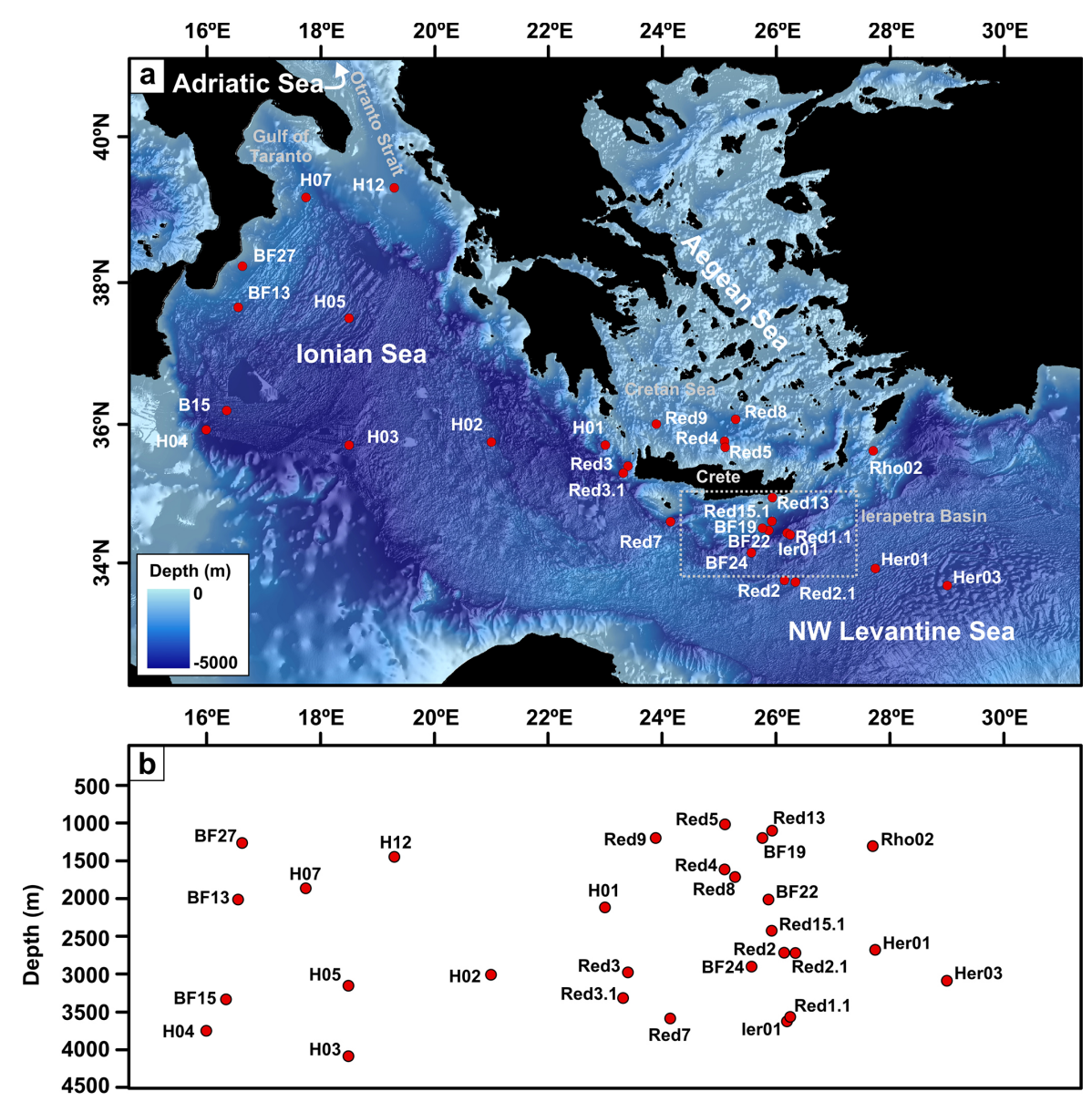

Figure 1. (a) Location of sampling sites across the open eastern Mediterranean Sea (see also Table 1). The map was produced using GEBCO Digital Atlas (IOC, IHO and BODC, 2003). (b) Plot of longitude vs. water depth of sampling stations.

de Madron et al., 2000; Kaiser et al., 2014). Consequently, sedimentary OM constitutes an heterogeneous and complex mixture of organic compounds with a wide range of chemical and physical properties (Mayer, 1994; Hedges and Oades, 1997; Hedges et al., 1997; Goñi et al., 1998). Therefore, the combined use of bulk geochemical indicators such as total nitrogen $(\mathrm{TN})$ to organic carbon $(\mathrm{OC})$ ratios, stable isotope of OC $\left(\delta^{13} \mathrm{C}\right)$ and molecular proxies such as lipid biomarkers can aid to gain knowledge on the origin, delivery and preservation of OM in marine sediments (Bouloubassi et al., 1997; Meyers, 1997; Goñi et al., 2003; Volkman, 2006).

The biogeochemical composition of sediments in deep basins of the oligotrophic eastern Mediterranean Sea (EMS), as well as the sources, transport and preservation of sedimentary OM, have been scarcely investigated so far. Previous studies have shown that the composition of surficial sediments is principally controlled by the geochemical characteristics of the source areas, the prevailing metoceanic conditions on the adjacent shelves, the contribution of atmospheric aerosols and the dominant regional circulation (e.g. Weldeab et al., 2002; Ehrmann et al., 2007; Hamann et al., 2008). Nev- ertheless, the factors involved in the supply, distribution and fate of sedimentary OM are still poorly known.

In the present study, surface sediments collected from deep slopes and basins of the EMS have been analysed for physical and geochemical parameters such as grain size distribution, lithogenic, calcium carbonate $\left(\mathrm{CaCO}_{3}\right)$, opal, $\mathrm{OC}$ and $\mathrm{TN}$ contents, along with molar TN / OC ratios, stable isotopic ratios of OC $\left(\delta^{13} \mathrm{C}\right)$ and selected lipid biomarkers. Our main goal is to investigate the spatial distribution and main sources of sedimentary $\mathrm{OM}$ and to evaluate the impact of autochthonous vs. allochthonous contributions in the study area. We also examine whether and up to which point general environmental factors, such as water mass circulation patterns and water column depth, could explain the observed deep-sea sediment geochemical properties.

\section{Oceanographic setting}

The EMS is a land-locked sea with a complex topography including shelves, slopes, ridges, seamounts, trenches and four main basins: the Adriatic Sea, the Ionian Sea, the Aegean Sea 
and the Levantine Sea (Fig. 1) (Amblàs et al., 2004; Medimap Group, 2007). The Ionian Sea to the west and the Levantine Sea to the east are longitudinally connected and cover most of the EMS area. They are also the deepest basins of the EMS, with the maximum depth $(5267 \mathrm{~m})$ located at the Hellenic Trench, south of the Cretan Arc. The Aegean Sea and the Adriatic Sea represent the northern extensions of the EMS. Both are relatively shallow, in particular the Adriatic Sea, which is dominated by a broad shelf and a slope subbasin shallower than $1200 \mathrm{~m}$. In the Aegean Sea, which has a particularly complex topography with tens of depressions, highs and islands, water depths up to $2500 \mathrm{~m}$ are found north of the island of Crete (Amblàs et al., 2004; Medimap Group, 2007). The southern Aegean Sea (Cretan Sea) is the sea area comprised between the Cyclades Archipelago to the north and the island of Crete to the south, which also includes the western Cretan Straits.

The general circulation pattern of the EMS is antiestuarine, which results from interactions between basin, sub-basin and mesoscale flows (Bethoux, 1979). The EMS communicates with the western Mediterranean Sea through the Sicily Strait, with an inflow of low-salinity modified Atlantic water (MAW) at the upper 100-150 m of the water column (Rabitti et al., 1994; Malanotte-Rizzoli et al., 1997). MAW flows in an easterly direction getting progressively saltier and warmer until it transforms into Levantine intermediate water (LIW) into the Levantine Sea where it sinks to mid depths (Milliff and Robinson, 1992; Lascaratos et al., 1993).

The eastern Mediterranean deep water (EMDW) is a relatively well-oxygenated water mass, likely as a result of the formation and sinking of warm deep-water that ventilates the deepest levels in the EMS (Schlitzer et al., 1991; Roether and Well, 2001; Meador et al., 2010). Waters from the Adriatic Sea (Adriatic deep waters) have been considered as the main contributor of deep and bottom waters to the EMS (Malanotte-Rizzoli and Hecht, 1988). Nevertheless, the Aegean Sea constitutes a sporadically significant contributor to EMDW through the Cretan deep waters, as in the case of the eastern Mediterranean Transient anomaly in the 1990s (Lascaratos et al., 1999; Theocharis et al., 1999). Additionally, the Aegean Sea constitutes a possible secondary source of intermediate waters to the adjacent Ionian and Levantine seas, through outflows across the Cretan Arc straits (Robinson et al., 2001).

Key factors that control the exchanges through the Cretan Arc straits are the thermohaline properties of water masses and mesoscale variability. For example, the Ierapetra anticyclonic gyre, which is located off the southeast corner of Crete (Ierapetra Basin), exhibits a strong seasonal signal that is linked to variations of the outflow across the eastern Cre$\tan$ Arc straits (Theocharis et al., 1993; Larnicol et al., 2002). Actually, the several permanent and/or recurrent eddies in each of the EMS sub-basins enhance exchanges between continental shelf and slope waters (Robinson et al., 1992;
Malanotte-Rizzoli et al., 1997; Millot and Taupier-Letage, 2005), which in turn influence primary productivity and the settling of OM to the deep-sea floor (Danovaro et al., 2010).

Thermohaline circulation and overall environmental conditions make the EMS one of the most ultra-oligotrophic environments of the world ocean (Psarra et al., 2000; Krom et al., 2005; Thingstad et al., 2005; Gogou et al., 2014). Annual primary production in the EMS averages between 121 and $145 \mathrm{~g} \mathrm{C} \mathrm{m}^{-2} \mathrm{yr}^{-1}$ (Bosc et al., 2004; Gogou et al., 2014). However, the fraction of primary production exported below $2000 \mathrm{~m}$ of water depth averaged $0.3 \%$ (Gogou et al., 2014). The low autochthonous contribution to OM fluxes in the deep open EMS is counterbalanced by allochthonous inputs resulting from long-range atmospheric transport and deposition by aerial dust (Jickells, 1995; Gogou et al., 1996; Tsapakis and Stephanou, 2005). The overall sedimentation rate in the deep areas of the open EMS is low (i.e. $2-5 \mathrm{~cm} \mathrm{kyr}^{-1}$ ) (Van Santvoort et al., 1996, 2002; Garcia-Orellana et al., 2009; Stavrakakis et al., 2013).

\section{Materials and methods}

\subsection{Sampling}

Short sediment cores were collected with a multicorer at 29 stations, ranging from 1018 to $4087 \mathrm{~m}$ water depth, during six oceanographic cruises in the Ionian Sea, the southern Aegean Sea (Cretan Sea) and the northwestern Levantine Sea from January 2007 to June 2012 (Fig. 1 and Table 1). Once onboard, multicores were visually described and sliced at $1 \mathrm{~cm}$ intervals. Sub-samples collected for grain size and elemental and stable isotopic composition were stored in sealed plastic bags at $4{ }^{\circ} \mathrm{C}$, while those collected for the analysis of lipid biomarkers were stored in pre-combusted aluminium foils at $-20^{\circ} \mathrm{C}$. Only the undisturbed top centimetre of each sediment core is considered in this study.

\subsection{Analytical procedures}

\subsubsection{Particle size characterization}

The grain size distribution of sediment samples was determined using a Coulter LS230 Laser Diffraction Particle Size Analyzer, which measures sizes between 0.04 and $2000 \mu \mathrm{m}$. Prior to analysis, freeze-dried samples were oxidized with a $10 \% \mathrm{H}_{2} \mathrm{O}_{2}(v / v)$ solution in order to remove OM. Each sample was then divided into two sub-samples, one of which was treated with $1 \mathrm{M} \mathrm{HCl}$ to remove carbonates and thus obtain the grain size distribution of lithogenic (siliciclastic) particles. Subsequently, both bulk and lithogenic fractions were dispersed into $20 \mathrm{~cm}^{3}$ of a $5 \% \mathrm{NaPO}_{5}(v / v)$ solution and mechanically shaken for $4 \mathrm{~h}$ and then introduced into the particle size analyzer after using a $2000 \mu \mathrm{m}$ sieve to retain occasional coarse particles that might obstruct the flow circuit of the instrument. 
The measured particle size spectrum is presented as \% volume in a logarithmic scale, where volume is calculated from particle diameter, assuming spherical shapes. Results were recalculated to percentages of clay $(<4 \mu \mathrm{m})$, silt $(4-63 \mu \mathrm{m})$ and sand $(63 \mu \mathrm{m}-2 \mathrm{~mm})$.

\subsubsection{Elemental and stable isotopic analysis of carbon and nitrogen}

For the determination of total carbon (TC), TN, OC contents and stable isotopic composition of $\mathrm{OC}\left(\delta^{13} \mathrm{C}\right)$ freeze-dried and ground sediments were analysed using a Flash 1112 EA elemental analyser interfaced to a Delta C Finnigan MAT isotope ratio mass spectrometer. Samples analysed for \% OC and $\delta{ }^{13} \mathrm{C}$ were initially de-carbonated using repetitive additions of a $25 \% \mathrm{HCl}(v / v)$ solution, separated by $60^{\circ} \mathrm{C}$ drying steps, until no effervescence was observed (Nieuwenhuize et al., 1994). Stable isotope data are reported using the conventional per thousand $\delta^{13} \mathrm{C}$ notation relative to the Pee Dee Belemnite standard. Uncertainties for elemental composition were lower than $0.1 \%$, while uncertainty for $\delta^{13} \mathrm{C}$ was lower than $0.05 \%$.

In consistency with published data in the Mediterranean Sea we assumed OM as twice the OC content (e.g. Heussner et al., 1996; Masqué et al., 2003). The inorganic carbon content was calculated from the difference between TC and OC measurements. Assuming all inorganic carbon is contained within calcium carbonate, $\mathrm{CaCO}_{3}$ content was determined using the molecular ratio of 100/12.

Molar TN/OC ratios were also calculated. TN/OC is plotted in order to constrain the elemental ratios of $\mathrm{N}$-depleted samples (i.e. $\mathrm{TN} / \mathrm{OC} \approx 0$ rather than OC / TN $\infty 0$ ) following Goñi et al. (2006) and to avoid the underestimation of the terrestrial-derived carbon fraction (Perdue and Koprivnjak, 2007).

\subsubsection{Biogenic opal and lithogenic fraction analysis}

The biogenic silica content was analysed using a two-step $2.5 \mathrm{~h}$ extraction with a $0.5 \mathrm{M} \mathrm{Na}_{2} \mathrm{CO}_{3}$ solution, separated by centrifugation of the leachates. $\mathrm{Si}$ and $\mathrm{Al}$ contents of both leachates were analysed with a Perkin-Elmer Optima 3200RL Inductive Coupled Plasma Optical Emission Spectrometer (ICP-OES), correcting the $\mathrm{Si}$ content of the first leachate by the $\mathrm{Si} / \mathrm{Al}$ ratio of the second one. All values are reported as opal $\left(\mathrm{SiO}_{2} \cdot 0.4 \mathrm{H}_{2} \mathrm{O}\right)$, a parameter defined by 2.4 times the weight percentage of biogenic Si content determined for each sample (Mortlock and Froelich, 1989). The opal detection limit, associated with the detection limit of the ICP-OES system, is approximately $0.2 \%$.

The lithogenic fraction was estimated by subtracting the concentration of the major constituents from total dry weight (\% lithogenic $=100-\left[\% \mathrm{OM}+\% \mathrm{CaCO}_{3}+\%\right.$ opal $\left.]\right)$. This fraction represents the residual component of particles such as quartz, feldspars, clay minerals and aluminosilicates (Mortlock and Froelich, 1989).

\subsubsection{Lipid biomarkers analysis and definitions of molecular indices}

The analytical procedure followed for the determination of lipid biomarkers has been previously presented in detail (Gogou et al., 1998, 2000, 2007). Briefly, freeze-dried sediment samples were initially solvent-extracted three times by sonication with a dichloromethane : methanol mixture $(4: 1$, $v / v)$. Combined extracts were subsequently separated into different compound classes by column chromatography using silica gel that had been activated for $1 \mathrm{~h}$ at $150^{\circ} \mathrm{C}$. The following solvent systems were used to elute different compound classes: (1) $n$-hexane (fraction $\mathrm{F}_{1}$, aliphatic hydrocarbons), (2) dichloromethane/n-hexane (fraction $\mathrm{F}_{2}$, carbonyl compounds) and (3) ethyl acetate $/ n$-hexane (fraction $\mathrm{F}_{3}$, alcohols, sterols).

$\mathrm{F}_{1}$ and $\mathrm{F}_{3}$ fractions were analysed by gas chromatography-mass spectrometry (GC-MS) while $\mathrm{F}_{2}$ fractions were analysed by gas chromatography using flame ionization detection (GC-FID). Hydroxyl-bearing compounds (fraction $\mathrm{F}_{3}$ ) were derivatized to the corresponding trimethylsilyl ethers prior to GC-MS analysis using N,O-bis-(trimethylsilyl)-trifluoroacetamide (BSTFA) $+1 \%$ trimethylchlorosilane (TMCS) for $1 \mathrm{~h}$ at $80^{\circ} \mathrm{C}$. Details regarding the $\mathrm{GC}$ instrumental parameters are presented elsewhere (Gogou et al., 2007; Parinos et al., 2013).

The individual lipids were identified by a combination of comparison of GC-retention times to authentic standards and comparison of their mass spectral data to those in the literature. Quantification was based on the GC-MS or GCFID response and comparison of peak areas with those of known quantities of standards added prior to the extraction of the sediment samples $\left(\left[{ }^{2} \mathrm{H}_{50}\right] n\right.$-tetracosane for $n$-alkanes, $n$ hexatriacontane for long-chain alkenones, $5 \alpha$-androstan- $3 \beta$ ol for sterols and heneicosanol for $n$-alkanols). The signal of the unresolved complex mixture (UCM) of aliphatic hydrocarbons was defined by the chromatographic area (fraction $F_{1}$ ) between the solvent baseline and the curve defining the base of resolved peaks. UCM quantification was performed relatively to $\left[{ }^{2} \mathrm{H}_{50}\right] n$-tetracosane using the average response factor of $n$-alkanes.

Procedural blanks processed in parallel to the samples were found to be free of contamination. Reproducibility of the analytical method based on multiple extractions of sediments was better than $6 \%$ in all cases.

A range of selected lipid biomarkers are considered in this study, namely long-chain $n$-alkanes and $n$-alkanols, longchain alkenones, long-chain diols and keto-ols and a suite of sterols, along with lipid biomarkers' indices, as proxies of organic matter sources and/or degradation. As OC can vary due to the supply of inorganic material (dilution effect) the con- 
Table 1. Location, depth and collection date of sediment samples.

\begin{tabular}{|c|c|c|c|c|c|}
\hline Sample code & Latitude $(\mathrm{N})$ & Longitude (E) & Water depth (m) & Date of collection & Physiographic regions \\
\hline \multicolumn{6}{|l|}{ Ionian Sea } \\
\hline \multicolumn{6}{|l|}{ North } \\
\hline H12 & 39.30 & 19.30 & 1450 & Jan 2007 & Otranto Valley \\
\hline H07 & 39.17 & 17.75 & 1866 & Jan 2007 & Taranto Valley \\
\hline \multicolumn{6}{|l|}{ Central } \\
\hline BF27 & 38.22 & 16.63 & 1264 & Jun 2009 & Calabrian Slope \\
\hline BF13 & 37.66 & 16.56 & 2012 & Jun 2009 & Calabrian Arc \\
\hline BF15 & 36.20 & 16.35 & 3335 & Jun 2009 & Ionian Basin \\
\hline H04 & 35.92 & 16.00 & 3750 & Jan 2007 & Ionian Basin \\
\hline \multicolumn{6}{|l|}{ West } \\
\hline H02 & 35.75 & 21.00 & 3008 & Jan 2007 & Ionian Basin \\
\hline H05 & 37.50 & 18.50 & 3154 & Jan 2007 & Ionian Basin \\
\hline H03 & 35.70 & 18.50 & 4087 & Jan 2007 & Ionian Basin \\
\hline \multicolumn{6}{|c|}{ S Aegean Sea (Cretan Sea) } \\
\hline Red5 & 35.68 & 25.10 & 1018 & May 2010 & Cretan Trough \\
\hline Red9 & 36.00 & 23.89 & 1200 & May 2011 & Cretan Trough \\
\hline Red4 & 35.76 & 25.10 & 1615 & May 2010 & Cretan Trough \\
\hline $\operatorname{Red} 8$ & 36.07 & 25.28 & 1715 & May 2011 & Cretan Trough \\
\hline \multicolumn{6}{|c|}{ W Cretan Straits } \\
\hline H01 & 35.70 & 23.00 & 2117 & Jan 2007 & Kythira Strait \\
\hline Red3 & 35.40 & 23.40 & 2976 & May 2010 & Antikythira Strait \\
\hline $\operatorname{Red} 3.1$ & 35.30 & 23.32 & 3317 & May 2010 & Antikythira Strait \\
\hline Red7 & 34.60 & 24.15 & 3589 & May 2011 & Ptolemy Strait \\
\hline \multicolumn{6}{|c|}{ NW Levantine Sea } \\
\hline \multicolumn{6}{|c|}{ Ierapetra Basin } \\
\hline Red13 & 34.95 & 25.93 & 1101 & Jun 2012 & Cretan-Rhodes Ridge \\
\hline BF19 & 34.51 & 25.76 & 1200 & Jun 2009 & Hellenic Trench \\
\hline BF22 & 34.48 & 25.87 & 2015 & Jun 2009 & Hellenic Trench \\
\hline Red15.1 & 34.61 & 25.92 & 2428 & Jun 2012 & Hellenic Trench \\
\hline Red1.1 & 34.40 & 26.25 & 3568 & Jun 2012 & Hellenic Trench \\
\hline Ier01 & 34.44 & 26.19 & 3626 & Jan 2007 & Hellenic Trench \\
\hline \multicolumn{6}{|l|}{ Open Sea } \\
\hline Rho02 & 35.62 & 27.70 & 1305 & Jan 2007 & Rhodes Strait \\
\hline Her01 & 33.92 & 27.74 & 2680 & Jan 2007 & EM Ridge \\
\hline Red2 & 33.74 & 26.15 & 2717 & May 2010 & EM Ridge \\
\hline Red2.1 & 33.71 & 26.34 & 2720 & May 2010 & EM Ridge \\
\hline BF24 & 34.15 & 25.57 & 2902 & Jun 2009 & Pliny Trench \\
\hline Her03 & 33.67 & 29.00 & 3090 & Jan 2007 & Herodotus Basin \\
\hline
\end{tabular}

January 2007 samples were collected during the M71 (Leg 3) cruise onboard the R/V Meteor (University of Hamburg, Germany), June 2009 samples during the Biofun1 cruise onboard the R/V Sarmiento de Gamboa (CSIC-UB, Spain) and May 2010, 2011 and June 2012 samples during the ReDEco cruises onboard the R/V Aegaeo (HCMR, Greece).

centrations of the reported lipid compounds were normalized to OC contents.

The sum of the concentrations of the most abundant high molecular weight $n$-alkanes and $n$-alkanols, which are major components of epicuticular higher plant waxes (Eglinton and

$$
\begin{aligned}
& \sum \operatorname{TerNA}=\sum n-\mathrm{C}_{27,29,31,33,} \\
& \sum \operatorname{TerN}-\mathrm{OH}=\sum n-\mathrm{C}_{24,26,28,30} .
\end{aligned}
$$
tively as 
The sum of the concentrations of the considered lipid biomarkers having a clear marine (algal) origin (see Sect. 5.1.2) was calculated as follows:

$$
\begin{aligned}
& \sum \mathrm{Mar}= \\
& \sum\left(28 \Delta^{5,22 E}+{ }_{30} \Delta^{22 E}+\mathrm{C}_{30} \text { diols \& keto-ols }+ \text { alkenones }\right) .
\end{aligned}
$$

The abundance of the UCM of aliphatic hydrocarbons, a commonly observed persistent contaminant mixture in marine sediments consisting of branched alicyclic hydrocarbons (Gough and Rowland, 1990), is used as an indicator of the contribution from degraded petroleum products, i.e. chronic oil pollution in the study area (Wang et al., 1999).

The carbon preference indices of long-chain $n$-alkanes $\left(\mathrm{CPI}_{\mathrm{NA}}\right)$ and $n$-alkanols $\left(\mathrm{CPI}_{\mathrm{N}-\mathrm{OH}}\right)$ have been used as indicators of terrestrial OM degradation with CPI values in fresh leaves being typically $>4$ (Collister et al., 1994). However, the abundance of non-degraded petroleum hydrocarbons could potentially bias (lower) $\mathrm{CPI}_{\mathrm{NA}}$ values with increasing petroleum contribution, since $n$-alkane compounds of petroleum products present $\mathrm{CPI}_{\mathrm{NA}}$ values $\sim 1$ (Wang et al., 1999). The indices were calculated respectively as

$$
\begin{gathered}
\mathrm{CPI}_{\mathrm{NA}}=\frac{\sum\left(\left[n-\mathrm{C}_{25}\right]-\left[n-\mathrm{C}_{33}\right]\right)}{\sum\left(\left[n-\mathrm{C}_{26}\right]-\left[n-\mathrm{C}_{34}\right]\right)}, \\
\mathrm{CPI}_{\mathrm{N}-\mathrm{OH}}=\frac{\sum\left(\left[n-\mathrm{C}_{24}\right]-\left[n-\mathrm{C}_{30}\right]\right)}{\sum\left(\left[n-\mathrm{C}_{23}\right]-\left[n-\mathrm{C}_{29}\right]\right) .}
\end{gathered}
$$

Finally, the abundance ratio of $\sum$ TerNA to $\sum$ TerN-OH is used as a proxy of the proportion of refractory vs. labile terrestrial components, since $\sum$ TerNA are more resistant to degradation than their alcohol counterparts (Eglinton and Hamilton, 1967; Ohkouchi et al., 1997). The ratio is defined as

$$
\frac{[\mathrm{NA}]}{[\mathrm{N}-\mathrm{OH}]}=\frac{\left[\sum \text { TerNA }\right]}{\left[\sum \mathrm{TerN}-\mathrm{OH}\right]} \text {. }
$$

\subsubsection{Data analysis and presentation}

Statistical treatment of grain size data was carried out using the GRADISTAT v. 8.0 software (Blott and Pye, 2001). Median diameter $\left(D_{50}\right)$, sorting and skewness were calculated geometrically (in metric units) following the approach of Folk and Ward (1957), which is most appropriate when data are non-normally distributed, as in the case of polymodal sediments from the study area.

$D_{50}$ was calculated as the average equivalent diameter, which is the diameter where $50 \%$ of the sediment sample has a larger equivalent diameter and the other $50 \%$ has a smaller equivalent diameter. Sorting (expressed by the standard deviation) indicates the fluctuation in the degree of kinetic energy and the depositional regime on grain size characteristics. Skewness measures the degree of asymmetry onto particle distribution. The skewness for a normal distribution is zero, and any symmetric data should have skewness near zero. Positive values indicate skewness towards the finer grain sizes (skewed left) while negative values indicate skewness towards the coarser grain sizes (skewed right). The results of grain size distribution analysis were hierarchically clustered (using IBM SPSS Statistics 18.0) according to the above statistical parameters (autoscaled prior to cluster analysis) in order to determine the similarity of samples within each station measuring the squared Euclidean distance.

Principal component analysis (PCA) was performed on standardized grain size and elemental composition data (\% clay and sorting of lithogenic and bulk fractions, lithogenic, $\mathrm{CaCO}_{3}, \mathrm{OC}$ and $\mathrm{TN}$ contents), on standardized bulk organic matter signatures (molar TN/OC ratios and $\delta^{13} \mathrm{C}$ ) and on standardized indices and mass-normalized concentrations of lipid biomarkers. A subroutine, the Varimax rotation, was applied to the first three factors in order to maximize or minimize loadings within each factor and thus simplify the visual interpretation of PCA projections. Correlation analysis was also performed using the same variables. In certain occasions during correlation analysis, the singular stations that were clearly out of the trend were excluded in order to strengthen the evident trends of the examined variables. These stations are explained in detail in the discussion section (see Sect. 5.2).

The spatial distribution of the various geochemical parameters' contents, bulk OM signatures and selected lipid biomarkers' concentrations/indices considered in this study were visualized using Ocean Data View (Schlitzer, 2011).

\section{Results}

\subsection{Grain size characteristics}

The grain size composition (\% clay, silt and sand) and the sedimentary parameters ( $D_{50}$, sorting and skewness) are presented in Table 2, while the statistical dendrogram, typeaveraged grain size spectrum and spatial distributions of grain size types are presented in Fig. 2.

Silt- and clay-sized particles dominate the bulk sediment, accounting for up to 76.7 and $57.1 \%$ of the total weight respectively (Table 2$)$. The lowest values $(<40 \%)$ for the silt fraction are found in the upper slope of the western Cretan straits (station Red3) and the northwestern Levantine Sea (station BF19), while the highest values ( $>65 \%$ ) correspond to the Ionian Sea (stations H12 and H03). The lowest clay contents $(<20 \%)$ are also found in the upper slope of the western Cretan Straits (station Red3) but also in the northeastern Ionian Sea (station H12), while maximum values (>55\%) are recorded at the northwestern Levantine Sea (station Red1.1 in Ierapetra Basin) and the western Cretan Straits (station H01). Sand contents show large variations, i.e. from 0 to $47.7 \%$ (station Red3 in the upper slope of western Cre- 


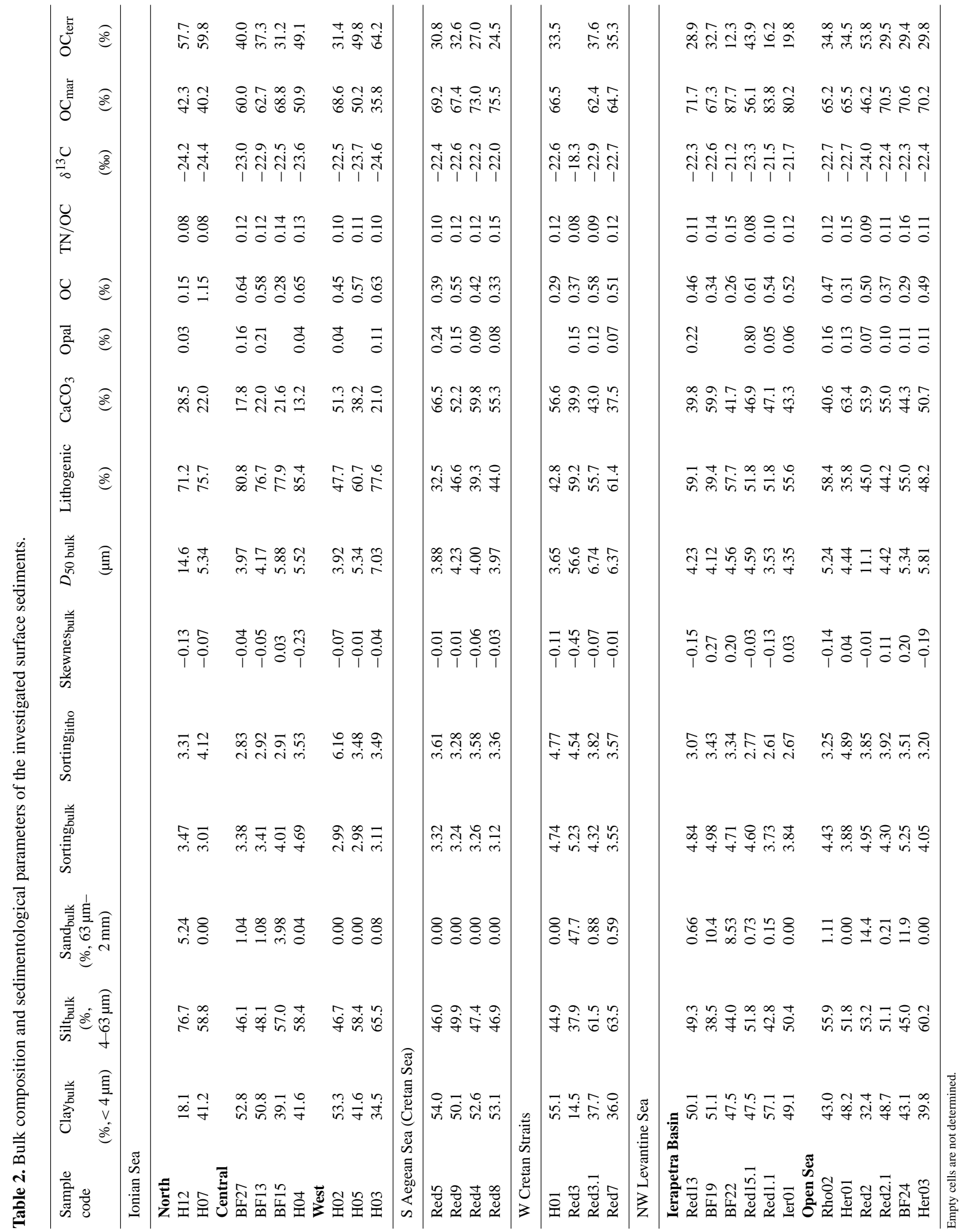


(a)
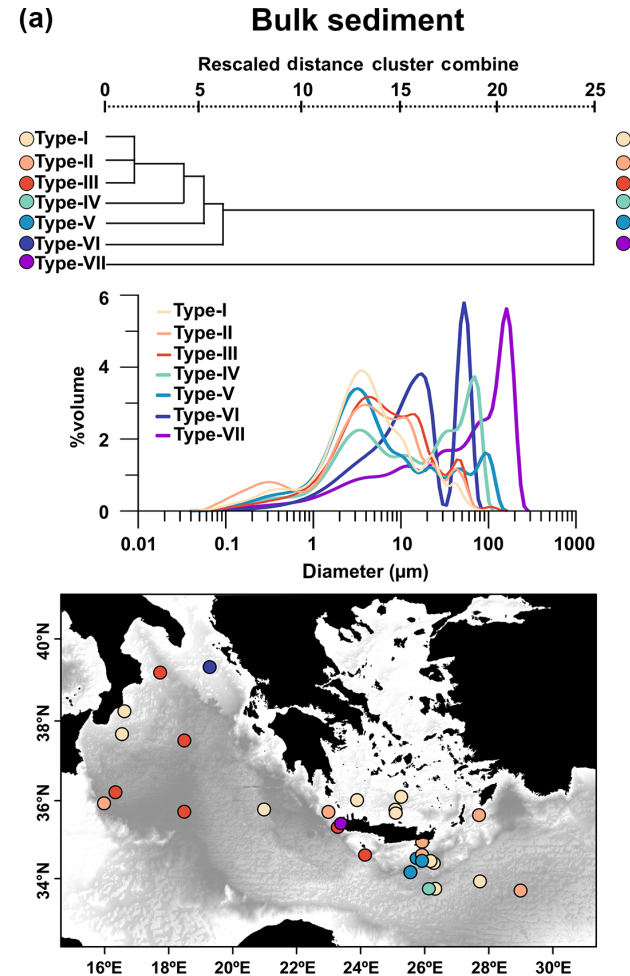

(b)
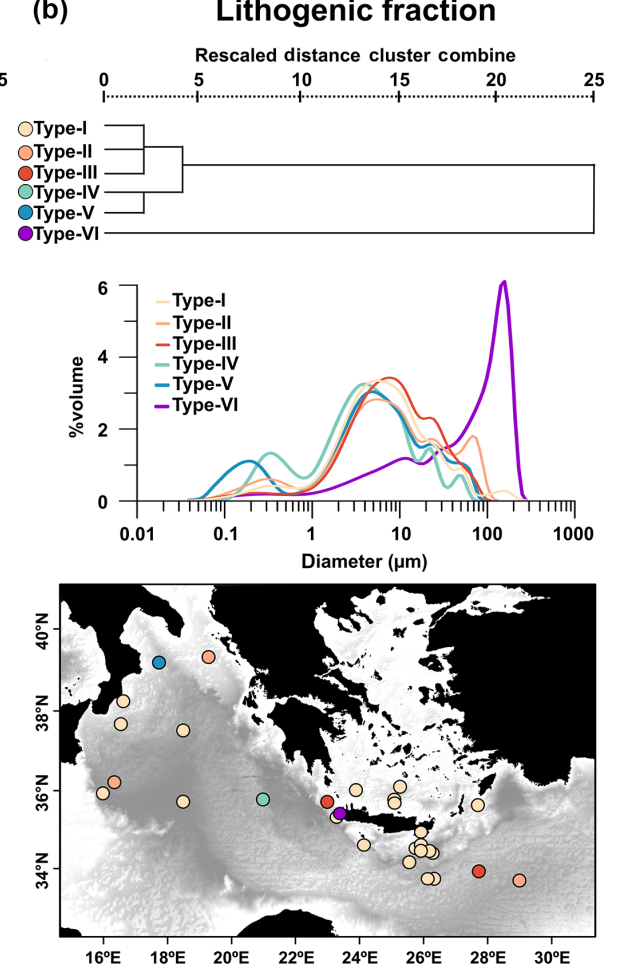

Figure 2. Statistical dendrogram of type-averaged grain size profiles and geographical distribution of grain size compositional types for (a) the lithogenic fraction and (b) the bulk fraction of the investigated sediments.

$\tan$ Straits), with values less than $2 \%$ in most of the stations (Table 2). Relatively high values $(>10 \%$ ) are also obtained in the northwestern Levantine Sea (stations Red2, BF19 and BF24). $D_{50}$ values range between 3.5 and $56.6 \mu \mathrm{m}$ (Table 2).

Sorting of bulk sediment ranges from 3.0 to 5.2 (Table 2). Most of the northwestern Levantine Sea and western Cretan Straits' stations are very poorly sorted and all stations within the southern Aegean Sea and most of the Ionian Sea are poorly sorted (Table 2 and Fig. 2a). Skewness values for the investigated samples range from -0.45 to 0.27 (Table 2), varying from a very clear negative skewness in the upper slope of the western Cretan Straits (station Red3), to positive skewness in the northwestern Levantine Sea (stations Red2.1, BF19, BF22 and BF24).

The hierarchical cluster analysis of all bulk sediment samples resulted into seven grain size types (Fig. 2a). Most of the samples group into cluster types I $(n=11)$, II $(n=6)$ and III $(n=6)$, with grain size profiles almost symmetrical and poorly sorted, and a dominance of clay and silt fractions. Type V includes three very poorly sorted and positive skewed samples from the northwestern Levantine Sea, which consist mainly of clay and silt fractions. Types IV, VI and VII include only one sample each (Red2, H12 and Red3 respectively). Samples Red2 and Red3, dominated by coarse silt fractions ( $D_{50} 11.1$ and $56.61 \mu \mathrm{m}$ respectively), are both very poorly sorted but with different types of skewed distributions (symmetrical and negatively skewed respectively). Finally, sample
H12, composed mostly of fine silt, is poorly sorted and slight positive skewness.

As in the bulk sediment, silt- and clay-sized particles dominate the lithogenic fraction, accounting for up to 73.5 and $50.8 \%$ of the total weight respectively. The hierarchical cluster analysis of the lithogenic fraction identified six grain size types (clusters) (Fig. 2b). A majority of samples are highly similar (types I-V), with an average composition of $35.2 \pm 5.6 \%$ clay, $63.5 \pm 5.3 \%$ silt and $1.3 \pm 2.3 \%$ sand, a $D_{50}$ of $6.6 \pm 1.3 \mu \mathrm{m}$ and a bimodal or trimodal, symmetrical, poorly sorted grain size distribution. Sample Red3 from the upper slope of western Cretan Straits is an exception, belonging to type VI. The composition of its lithogenic fraction is $10.3 \%$ clay, $34.6 \%$ silt and $55.1 \%$ sand, with a $D_{50}$ of $78.1 \mu \mathrm{m}$ and a bimodal, very poorly sorted and negatively skewed grain size distribution (Fig. 2b and Table 2).

\subsection{Bulk geochemical sediment composition}

The spatial variability of lithogenics, $\mathrm{CaCO}_{3}, \mathrm{OC}$ and $\mathrm{TN}$ contents within the study area is presented in Fig. $3 \mathrm{a}-\mathrm{c}$.

The lithogenics content in the analysed surface sediments range between 32.5 and $85.4 \%$ (Fig. 3a). Higher percentages $(>70 \%)$ are found in stations of the Ionian Sea (with the exception of station H02), while the lowest percentages $(<40 \%)$ are found in the southern Aegean (stations Red4 and Red5) and northwestern Levantine seas (stations 
Her01 and BF19) (Table 2). The $\mathrm{CaCO}_{3}$ contents also show a wide range of values throughout the study area, from 13.2 to $66.5 \%$ (Fig. $3 \mathrm{~b}$ and Table 2). Stations in the western Ionian Sea (H04, BF27, H03, BF15, BF13 and H07) have the lowest $\mathrm{CaCO}_{3}$ contents $(<22 \%)$, whereas most stations in the southern Aegean and northwestern Levantine seas and in the western Cretan Straits have elevated $\mathrm{CaCO}_{3}$ contents (> $40 \%)$.

Opal contents are very low, ranging from below detection limits to a maximum of $0.24 \%$ in the southern Aegean and northwestern Levantine seas (stations Red5 and Red13) (Table 2). Since opal contents are very close to the detection limits, those values can be considered as negligible. Therefore inorganic geochemical fraction of the investigated deep EMS sediments consists only of lithogenic (terrigenous) and carbonate components.

OC contents in the studied samples range from 0.15 to $1.15 \%$, with an average value of $0.47 \%$ (Table 2). The lowest values are recorded in the northeastern Ionian Sea, south of Otranto Strait (station H12), while the highest values are found off the Gulf of Taranto (station H07), followed by stations in the Ionian Sea (stations BF27, H04 and H03). TN contents range from 0.01 to $0.11 \%$ with an average value of $0.06 \%$. TN display a pattern similar to OC, also with the highest values recorded off the Gulf of Taranto (station H07) and the lowest south of Otranto Strait (station H12), both in the northern Ionian Sea.

\subsection{Elemental and stable isotopic composition of sedimentary OM}

The spatial distribution of molar TN / OC ratios and $\delta^{13} \mathrm{C}$ within the study area is presented in Fig. 3d-e.

Molar TN / OC ratios of the sedimentary OM range from 0.08 to 0.16 (Fig. 3d and Table 2). The highest molar $\mathrm{TN} / \mathrm{OC}$ ratios values $(>0.14)$ are recorded in the southern Aegean (station Red8) and northwestern Levantine (stations Her01, BF22 and BF24) seas, whereas the lowest molar TN / OC ratios $(<0.09)$ are recorded in stations from the northwestern Levantine Sea (station Red15.1), the western Cretan Straits (stations Red3 and Red3.1) and the northern Ionian Sea (stations H07 and H12). However, there is no clear spatial trend (Fig. 3d).

The spatial distribution of $\delta^{13} \mathrm{C}$ values shows that relatively lower values are more common in the Ionian Sea than in the northwestern Levantine Sea, the southern Aegean Sea and the south Ionian Sea (Fig. 3e). $\delta{ }^{13} \mathrm{C}$ values range from -18.3 to $-24.6 \%$ (Fig. 3e and Table 2), with stations from the Ionian Sea (stations H03, H07 and H12) yielding relatively depleted $\delta^{13} \mathrm{C}$ values $(<-24 \%$ ) and stations from the western Cretan Straits (station Red3) and the northwestern Levantine Sea (Ierapetra Basin, stations BF22, Red1.1 and Ier01) having relatively enriched $\delta^{13} \mathrm{C}$ values $(>-22 \%$ ).

\subsection{Lipid biomarkers}

The analysed sedimentary aliphatic hydrocarbons comprise of a series of resolved compounds, mainly $n$-alkanes, and a UCM (Parinos et al., 2013). The UCM dominate amongst aliphatic hydrocarbons in concentrations ranging between 0.50 and $6.64 \mathrm{mg} \mathrm{g} \mathrm{OC}^{-1}$ (Fig. 4a and Table 3). Maximum concentrations (> $\mathrm{mg} \mathrm{g} \mathrm{OC}^{-1}$ ) are recorded in the northwestern Levantine Sea (station Red2.1) followed by the deep central Ionian Sea (station H03). The lowest UCM values $\left(<1.0 \mathrm{mg} \mathrm{g} \mathrm{OC}^{-1}\right)$ are obtained in the northern Ionian Sea (station H12) and in the western Cretan Straits (station H01), while rather low values are also recorded in the southern Aegean Sea and west of Crete.

The molecular profile of the $n$-alkanes is dominated by long-chain homologues $\left(\mathrm{C}_{n} \geq 24\right)$, maximizing at $n$ - $\mathrm{C}_{31}$, with elevated $\mathrm{CPI}_{\mathrm{NA}}$ values $(4.9 \pm 1.6)$ (Table 3$)$. $\sum$ TerNA range between 40.8 and $483 \mu \mathrm{g} \mathrm{OC}^{-1}$, with an average value of $172 \mu \mathrm{g} \mathrm{OC}^{-1}$ (Fig. $4 \mathrm{~b}$ and Table 3). The station with the highest concentration (station Red2.1) is found in the northwestern Levantine Sea, while the stations with the lowest ones $\left(<110 \mu \mathrm{g} \mathrm{OC}^{-1}\right)$ are located in the northern Ionian Sea (stations H07 and H12) and in the southern Aegean Sea (station Red9). Furthermore, relatively elevated $\sum$ TerNA concentrations $\left(>210 \mu \mathrm{g} \mathrm{OC}^{-1}\right)$ are recorded at the deep station of the western Cretan Straits' (station Red3.1) and the deep central Ionian Sea (stations H03 and $\mathrm{H} 05)$.

The aliphatic alcohol fraction is dominated by a series of $n$-alkanols ranging from $n-\mathrm{C}_{22}$ to $n-\mathrm{C}_{30}$, with maxima at $n$ - $\mathrm{C}_{26}$ and elevated $\mathrm{CPI}_{\mathrm{N}-\mathrm{OH}}$ values $(4.5 \pm 0.8)$ (Table 3 ). $\sum$ TerN-OH range from 13.4 to $105 \mu \mathrm{g} \mathrm{g} \mathrm{OC}{ }^{-1}$, with an average of $40.4 \mu \mathrm{g} \mathrm{g} \mathrm{OC}-1$, displaying similar distribution with $\sum$ TerNA (Fig. $4 \mathrm{c}$ and Table 3). The $[\mathrm{NA}] /[\mathrm{N}-\mathrm{OH}]$ ratios for the analysed sediments range between 2.9 and 6.9 , with an average of $4.3 \pm 0.9$ (Table 3 ).

Long-chain di- and tri-unsaturated $\mathrm{C}_{37}$ and $\mathrm{C}_{38}$ methyl ketones and $\mathrm{C}_{38}$ ethyl ketones, commonly referred to as long-chain alkenones, are present in all samples with total concentrations ranging from 3.41 to $30.5 \mu \mathrm{g} \mathrm{OC}^{-1}$, $13.0 \mu \mathrm{g} \mathrm{g} \mathrm{OC}^{-1}$ on average. The major $\mathrm{C}_{27}-\mathrm{C}_{30}$ sterols considered in this study, i.e. cholesterol (cholest-5-en- $3 \beta$-ol; ${ }_{27} \Delta^{5}$ ), brassicasterol (24-methylcholesta-5,22-dien-3 $\beta$-ol; $\left.{ }_{28} \Delta^{5,22}\right), \beta$-sitosterol (24-ethylcholesta-5-en-3 $\beta$-ol; $29 \Delta^{5}$ ) and dinosterol $(4 \alpha, 23,24$-trimethyl- $5 \alpha(\mathrm{H})$-cholest-22(E)-en$3 \beta$-ol $-{ }_{30} \Delta^{22}$ ), have total concentrations ranging between 10.3 and $62.4 \mu \mathrm{g} \mathrm{OC}^{-1}$, averaging $31.7 \mu \mathrm{g} \mathrm{OC}^{-1}$. Longchain $\mathrm{C}_{30} n$-alkan-1,15-diols and the corresponding $\mathrm{C}_{30}$ keto-ols are also found in concentrations ranging from 7.30 to $35.8 \mu \mathrm{g} \mathrm{OC}^{-1}$, with an average of $20.3 \mu \mathrm{g} \mathrm{OC}^{-1}$ (Table 3).

$\sum$ Mar range between 18.2 and $72.6 \mu \mathrm{gg} \mathrm{OC}^{-1}$, $43.6 \mu \mathrm{g} \mathrm{OCC}^{-1}$ on average (Fig. $4 \mathrm{~d}$ and Table 3), displaying a generally increasing eastward trend with maximum concentrations ( $>55 \mu \mathrm{g} \mathrm{OC}^{-1}$ ) recorded in the deep north- 


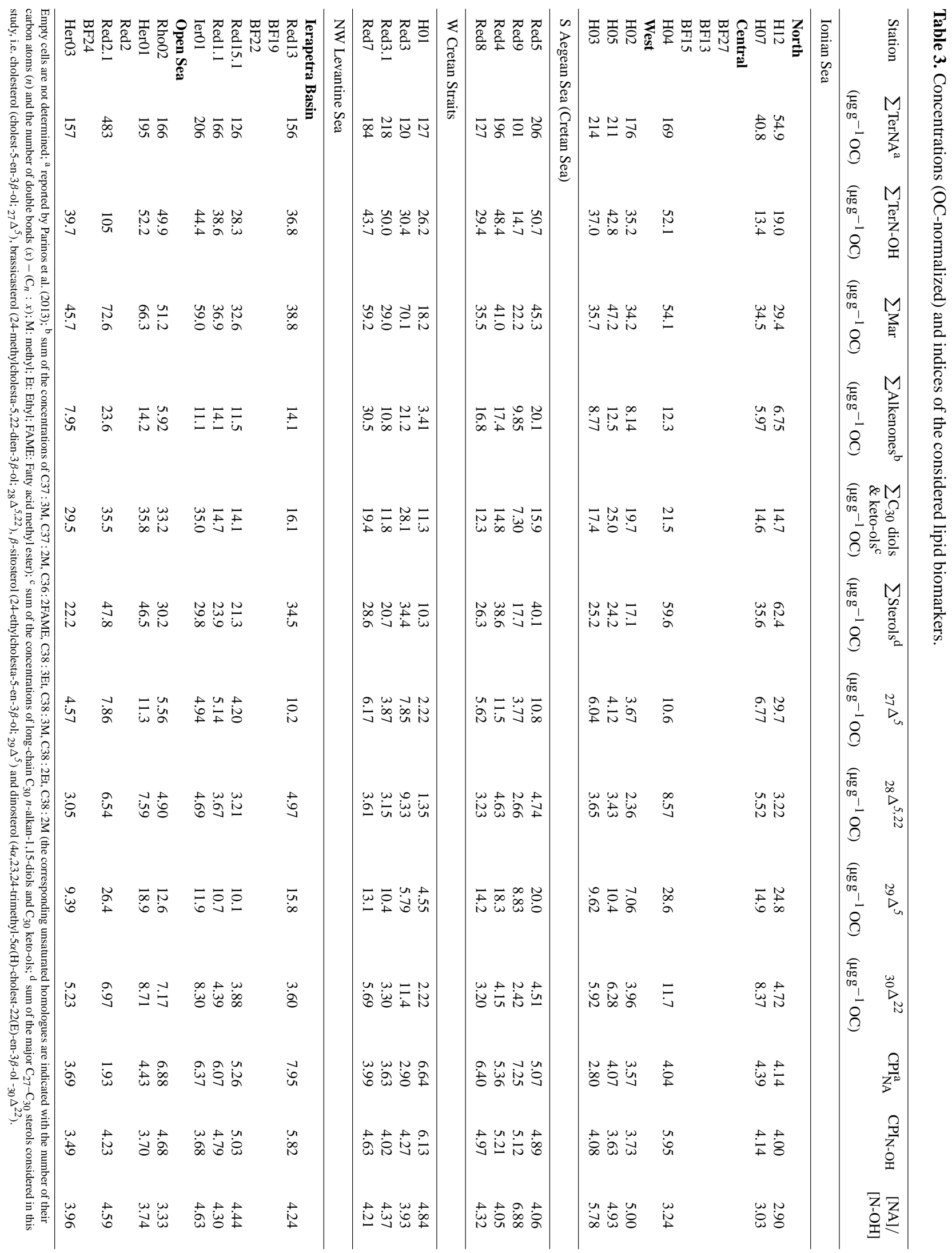



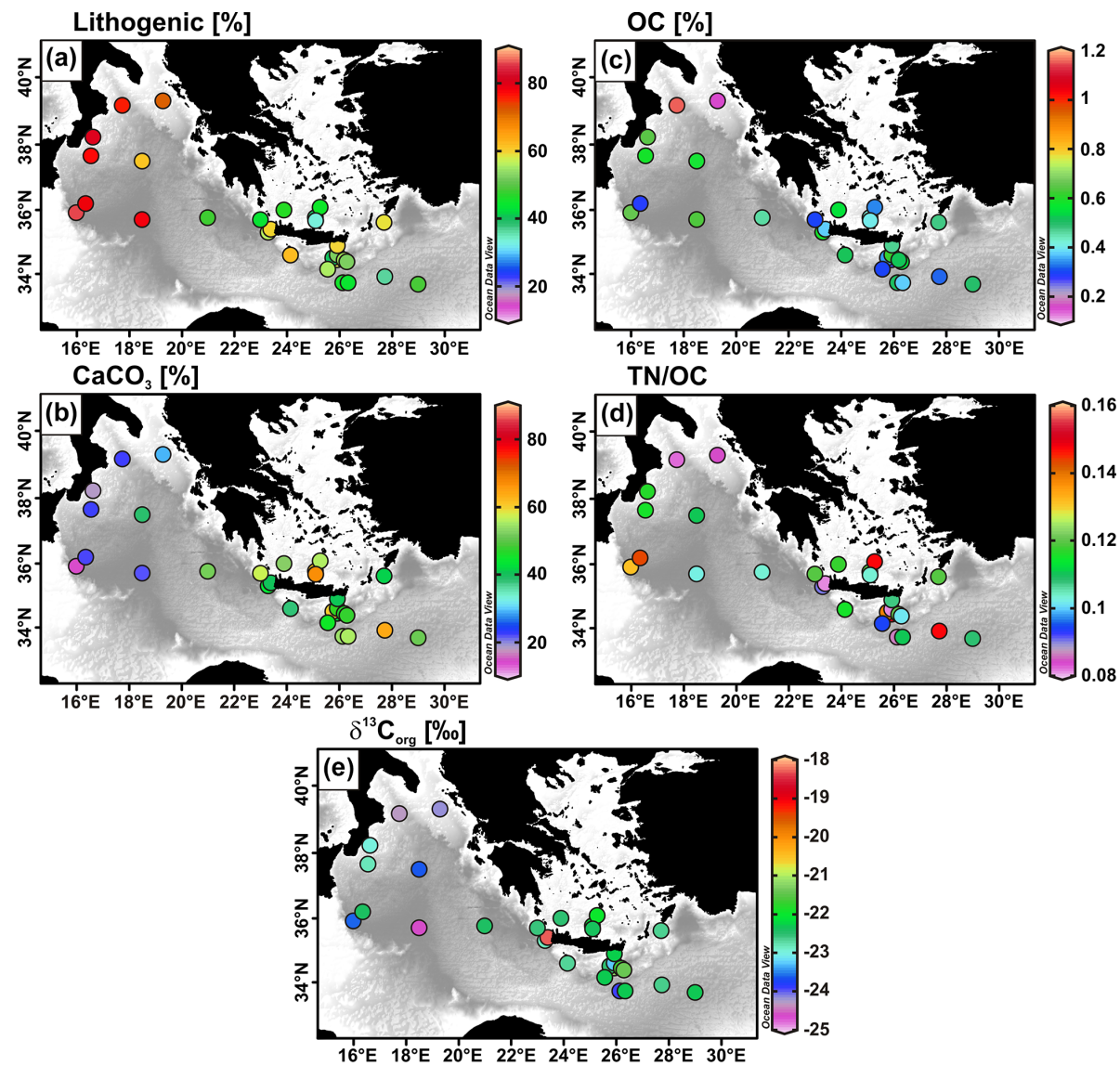

Figure 3. Spatial distribution of (a) lithogenics, (b) $\mathrm{CaCO}_{3}$ contents, (c) $\mathrm{OC}$ contents, (d) molar $\mathrm{TN} / \mathrm{OC}$ ratios and (e) $\delta^{13} \mathrm{C}$ values in surface sediments of the deep eastern Mediterranean Sea.
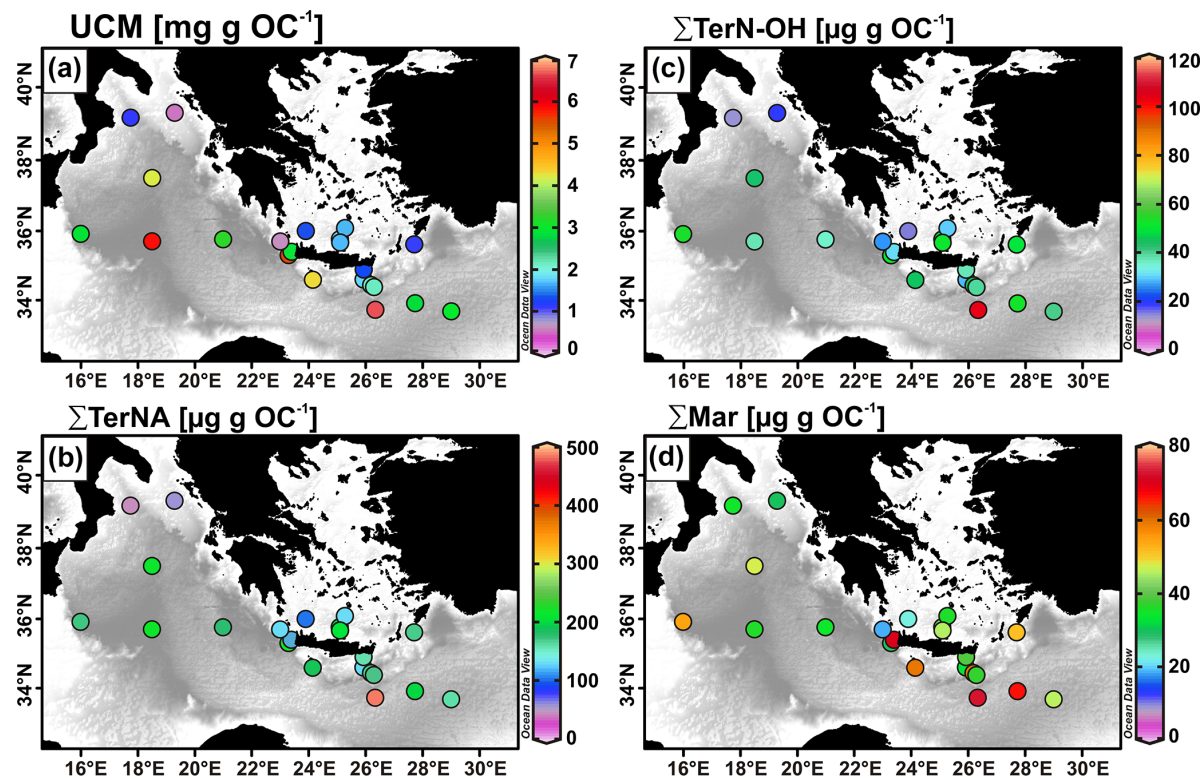

Figure 4. Spatial distributions of the OC-normalized concentrations of (a) unresolved complex mixture (UCM), (b) $\sum$ TerNA, (c) $\sum$ TerN$\mathrm{OH}$ and (d) $\sum \mathrm{Mar}$ in surface sediments of the deep eastern Mediterranean Sea. Abbreviations of lipid biomarkers are defined in the text. 
western Levantine Sea (stations Red2.1, Her01, Ier01 and Red7). Elevated $\sum$ Mar values are also recorded at stations Red3 in the upper slope of the western Cretan Straits as well as stations H04 and H05 in the deep Ionian Sea. The lowest values $\left(<40 \mu \mathrm{g} \mathrm{g} \mathrm{OC}{ }^{-1}\right)$ are obtained in the southern Aegean Sea (stations Red8, Red9), the northern Ionian Sea (station H12) and the western Cretan Straits (station H01).

\subsection{Multivariate analysis of geochemical parameters}

Three main principal components (PCs) are identified from PCA, accounting for $64.3 \%$ of the variation within the data set $(23.8,22.8$ and $17.7 \%$ for PC1, PC2 and PC3 respectively). $\mathrm{PC} 1$ is characterized by positive loadings for water depth, $\sum$ TerNA, $\sum$ TerN-OH, $\sum$ Mar, UCM and negative loadings for $\mathrm{CPI}_{\mathrm{NA}}$ and $\mathrm{CPI}_{\mathrm{N}-\mathrm{OH}}$. The highest positive loadings on $\mathrm{PC} 2$ are associated to $\% \mathrm{CaCO}_{3}, \%$ clay in the bulk sediment and TN/OC values, while negative loadings are associated to \% lithogenics. Finally, the geochemical parameters with high positive loadings on PC 3 are $\%$ OC, $\%$ TN and $\%$ clay of the lithogenic fraction, while those with negative loadings are $\delta^{13} \mathrm{C}$ and sorting of bulk sediment (Fig. 5a).

Factor scores on each PC display significant variability amongst the studied stations, both within the same area and from one area to another (Fig. 5b). High positive factor scores on PC1 are observed both in stations to the west (Ionian Sea) and east (western Cretan Straits and northwestern Levantine Sea). For PC2, an eastward increasing contribution of positive factor score values seems to exist, with the highest ones located in the southern Aegean Sea and the northwestern Levantine Sea. In contrast, the prevalence on PC3 is recorded in stations of the Ionian Sea and in parts of the northwestern Levantine Sea (Ierapetra Basin).

The contents of $\mathrm{CaCO}_{3}$ show an increasing north-south and west-east gradient (Figs. $3 b$ and 5). In the southern Aegean Sea, the northwestern Levantine Sea and the western Cretan Straits' stations, $\mathrm{CaCO}_{3}$ contents are positively correlated to \% clay of the bulk sediment $(r=0.48, p<0.05)$ and to alkenone concentrations $(r=0.62, p<0.05)$. Lithogenic contents are higher in the north and west (Ionian Sea) while being significantly positively correlated to $\mathrm{OC}$ and TN contents $(r=0.65$ and $r=0.72, p<0.05$ respectively excluding stations BF15, H07 and H12 of the Ionian Sea). Furthermore, OC and TN contents of stations deeper than $2100 \mathrm{~m}$ show a significant positive correlation to water depth $(r=0.54$ and 0.70 respectively $p<0.05$ ). However, this is not highlighted by the PCA. A significant positive correlation is also observed for $\mathrm{OC}$ and $\mathrm{TN}$ contents in the analysed samples $(r=0.87, p<0.0001)$ (Fig. 6a).

Surface sediments of the Ionian Sea show a significant $(p<0.05)$ positive correlation of OC and TN contents to $\%$ clay ( $r=0.80$ and $r=0.73)$ and a negative correlation to \% silt $(r=-0.75$ and -0.65$)$ and $D_{50}$ of the lithogenic fraction $(r=-0.79$ and -0.83$) . \delta^{13} \mathrm{C}$ values (excluding station Red 3 of the western Cretan Straits) are significantly $(p<0.05)$ and

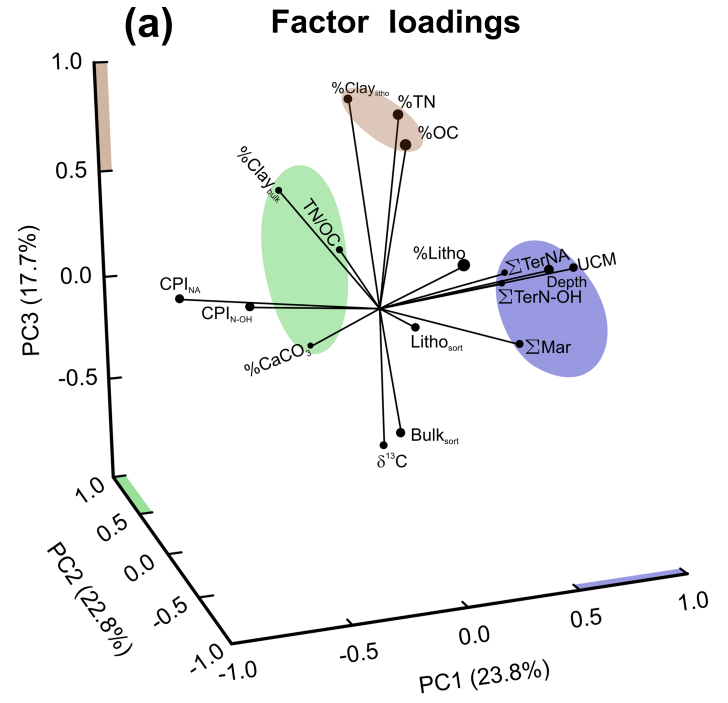

(b)

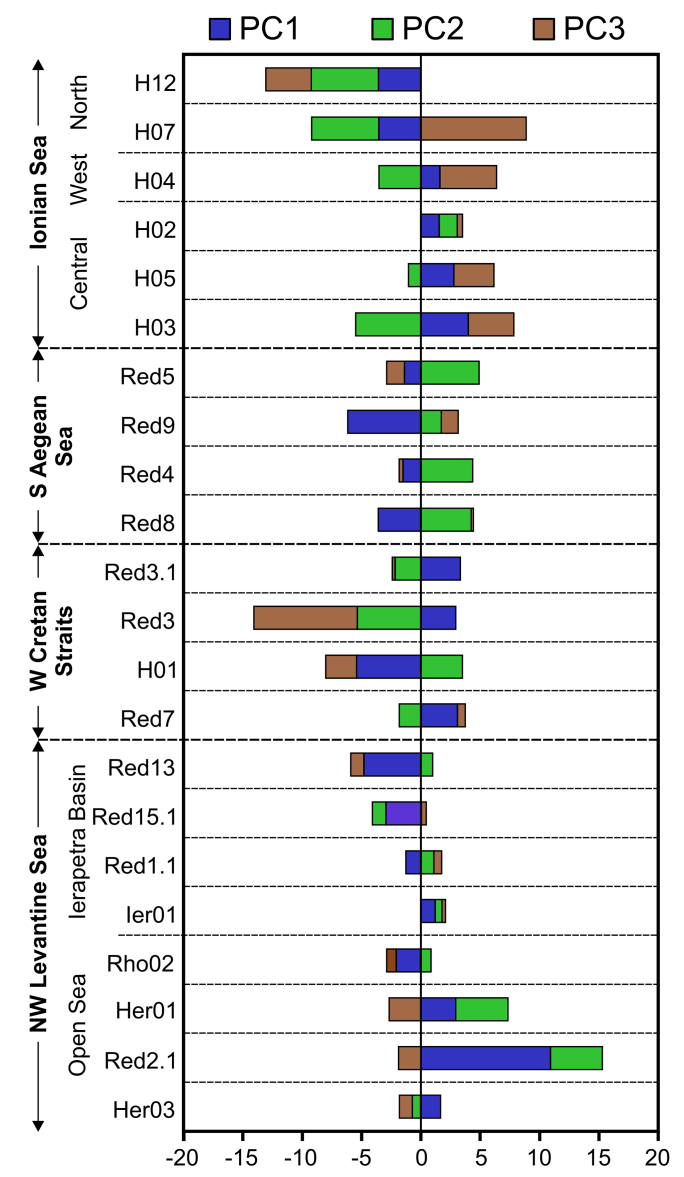

Figure 5. (a) Scatter plot of the factor loadings of the three principal components obtained in the principal component analysis; (b) plot of the scores found at each station. Abbreviations of lipid biomarkers are defined in the text. 

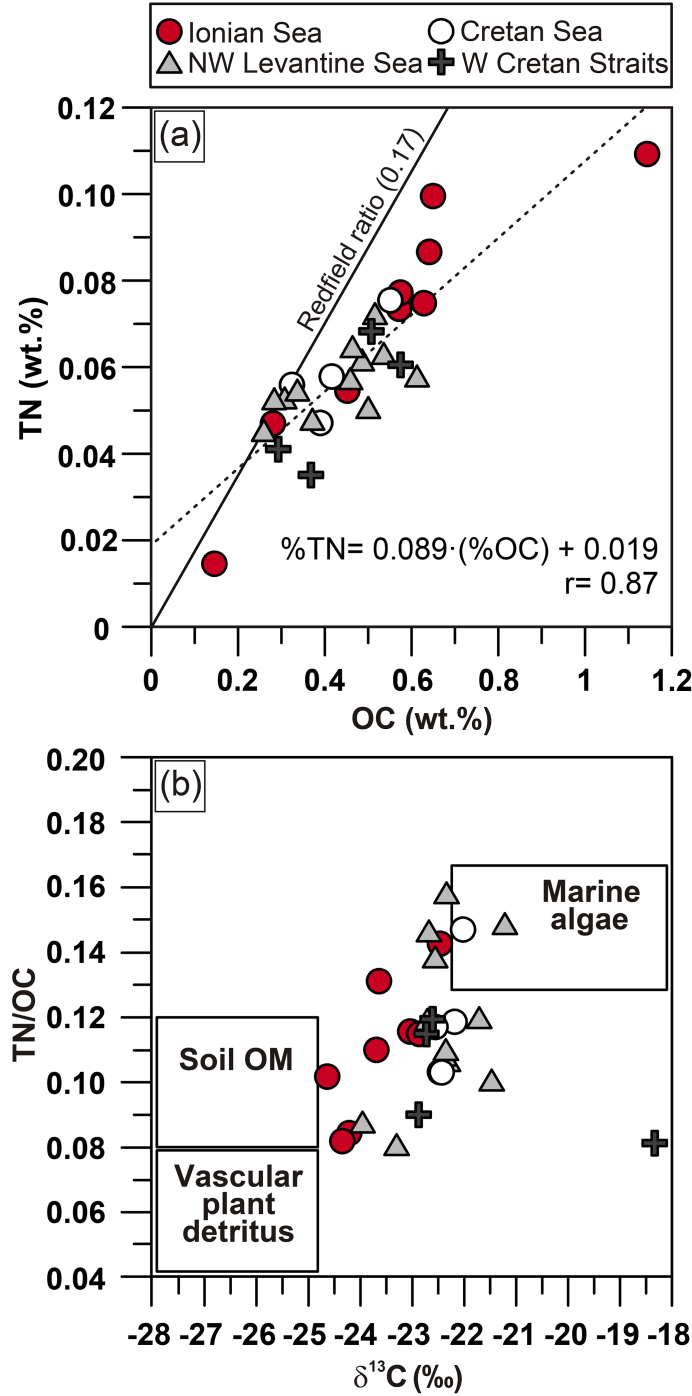

Figure 6. (a) Co-plot of the weight percent content of nitrogen (TN) vs. organic carbon (OC) for the deep-sea surface sediments analysed. The linear fit of the data is shown (dotted line) along with the Redfield ratio $\mathrm{N}_{16} / \mathrm{C}_{106}$ associated with the fresh marine phytoplankton $(0.17 \mathrm{wt} / \mathrm{wt})$. (b) Plot of molar TN / OC ratios vs. $\delta^{13} \mathrm{C}$, in surface sediments of the deep eastern Mediterranean Sea. The compositional ranges of organic matter sources illustrated in plots (boxes) derive from previously published studies (see Sect. 5.1).

positively correlated to $\mathrm{CaCO}_{3}$ contents $(r=0.53), \%$ clay of the bulk sediment $(r=0.65)$ and molar TN / OC ratios $(r=0.53)$ and negatively correlated to \% OC $(r=-0.46)$, $\%$ silt $(r=-0.66)$ and $D_{50}(r=-0.59)$ of the bulk sediment.

Terrestrial lipid biomarkers concentrations ( $\sum$ TerNA and $\left.\sum \mathrm{TerN}-\mathrm{OH}\right)$ display a significant positive correlation amongst them $(r=0.95, p<0.0001)$, as well as to \% clay (both with $r=-0.55, p<0.05)$ and $D_{50}(r=0.62$ and 0.58 respectively $p<0.01$ ) of the bulk lithogenic fraction. Moreover, $\sum$ TerNA and $\sum$ TerN-OH show a significant positive correlation $(p<0.05)$ to $\beta$-Sitosterol $\left({ }_{29} \Delta^{5}\right)(r=0.71$ and
0.56 respectively excluding stations $\mathrm{H} 07$ and $\mathrm{H} 12$ of the Ionian Sea). $\sum$ TerNA and $\sum$ TerN-OH (not normalized to OC contents) are also significantly correlated to OC $(r=0.81$ and 0.76 respectively $p<0.001$ ), again excluding stations H07 and H12 of the Ionian Sea. ¿Mar (not normalized to OC contents) displays a significant positive correlation with OC $(r=0.7, p<0.001)$, while a significant positive correlation ( $r>0.65, p<0.005$ in all cases) is evident amongst the concentration of cholesterol $\left({ }_{27} \Delta^{5}\right)$ and marine algal mark$\operatorname{ers}\left(28 \Delta^{5,22 E},{ }_{30} \Delta^{22 E}, \mathrm{C}_{30}\right.$ diols\&keto-ols and alkenones; see Sect. 5.2.1).

\section{Discussion}

\subsection{Sources of sedimentary material in the deep eastern Mediterranean Sea}

Clearly, the surface sediments of the deep EMS mostly consist of lithogenics and carbonates, with low OC contents while opal is nearly absent (Table 2). The range of lithogenics, carbonates and opal contents recorded in the investigated samples are similar to those previously reported for the eastern Mediterranean Sea (Emelyanov and Shimkus, 1986; Bethoux, 1989; Cros, 1995; Kemp et al., 1999; Rutten et al., 2000; Struck et al., 2001). OC contents reach values slightly above $1 \%$ and are also comparable to those found in the eastern Mediterranean Sea (0.56-1.51 \%, Danovaro et al., 1993; 0.23-0.99\%, Bianchi et al., 2003; 0.30-0.82 \%, Gogou et al., $2000 ; 0.25-1.73 \%$, Polymenakou et al., 2006) and relatively lower than those found in the western Mediterranean Sea (0.80-1.60\%, Kaiser et al., 2014; 0.47-1.53\%, Masqué et al., 2003; 0.23-1.85\%, Roussiez et al., 2006). Values found are comparable to the typical hemipelagic sediments found in continental slopes (Rullkötter, 2006) and slightly higher than those in deep basin areas (Seiter et al., 2004).

\subsubsection{Lithogenics and carbonate}

The grain size of the lithogenic fraction found in the studied sediments is very similar to that of Saharan dust particles, which mainly consist of clayey silts and silty clays with diameters ranging from 0.5 to $60 \mu \mathrm{m}\left(D_{50} \sim 5 \mu \mathrm{m}\right)$ and two main modes at 3-4 and $60 \mu \mathrm{m}$ (Ratmeyer et al., 1999; Guerzoni and Molinaroli, 2005 and references therein). This strongly suggests that the Sahara is the main source of lithogenics to the deep EMS. This is further supported by observations pointing to Saharan dust transported by southerlies blowing over the great North African desert as the main lithogenic input to the EMS (Guerzoni et al., 1999; Weldeab et al., 2002). The Saharan dust spreads rather uniformly across the EMS (Rutten et al., 2000; Jickells et al., 2005). Furthermore, to a lesser extent volcanic ash deposition into the EMS represents another external source of fine-grained particles $(<5-50 \mu \mathrm{m})$ (Kelepertsis et al., 2003). Mount Etna, located on the island of Sicily, generates volcanic ash plumes 
that are transported by the wind reaching as far as Greece and Libya (Olgun et al., 2013 and references therein).

Riverine inputs have a rather minor influence onto the open EMS sedimentation as they are small and localized (Weldeab et al., 2002; Statham and Hart, 2005). The relatively higher lithogenic contents found in most of the Ionian Sea stations (Fig. 3a and Table 2) points to fluvial inputs reaching the area from the Adriatic Sea. The main source of riverine inputs is the Po River, opening into the northernmost end of the Adriatic Sea, although inputs from smaller rivers draining the Apennines could be also relevant (Weldeab et al., 2002). In the Ionian Sea, river-sourced particles are carried by both surface and deep currents flowing southwards along the Italian Peninsula as part of the overall anticlockwise circulation in the Adriatic Sea (Orlic et al., 1992). It should be noted that dense water formation takes place seasonally in the Adriatic Sea, which triggers episodes of fast-flowing, sediment-loaded dense near-bottom currents that cascade into the deeper Meso Adriatic depression before passing through the Otranto Strait, subsequently spreading into the Ionian Sea where their particle load settles to the bottom (e.g. Zoccolotti and Salusti, 1987; Manca et al., 2002; Canals et al., 2009).

The grain size variability of the carbonate particles recorded in the studied sediment samples is indicative of calcareous skeletons of primary producers. While the abundance of particles $<8 \mu \mathrm{m}$ is attributable to coccoliths, which is the most abundant primary producer in the EMS (Emelyanov and Shimkus, 1986), coarser carbonate particles mostly correspond to shells and fragments of calcareous dinoflagellates and planktonic foraminifers, in agreement with Ziveri et al. (2000) and Frenz et al. (2005). Although part of the carbonate fraction might also have a terrestrial provenance as transported, for instance, with Saharan dust (Chester et al., 1977; Correggiari et al., 1989; Rutten et al., 2000), this does not seem to be the case with the investigated samples. Like other aeolian particles, aeolian carbonates are typically better sorted than those formed in situ, as shown by a well-sorted unimodal distribution due to gravitational settling during atmospheric transport (Skonieczny et al., 2013). The predominance of very poorly sorted grain size distributions within the bulk sediment samples (Fig. 2a) and the highly variable $\mathrm{CaCO}_{3}$ contents (Fig. 3b) in the investigated samples suggests that even within such a highly oligotrophic environment biogenic carbonates are the main source of $\mathrm{CaCO}_{3}$ in the deep EMS.

\subsubsection{Sources of sedimentary organic matter}

Bulk geochemical proxies such as elemental (TN / OC) and stable isotopic ratios of OC $\left(\delta^{13} \mathrm{C}\right)$ have been widely used to assess the sources of OM in marine sediments (Meyers, 1994; Goñi et al., 2003; Hu et al., 2006). Sedimentary molar $\mathrm{TN} / \mathrm{OC}$ ratios and $\delta^{13} \mathrm{C}$ values determined in this study are consistent with values previously reported for surface sedi- ments of the deep EMS (Tesi et al., 2007b; Meyers and Arnaboldi, 2008; Carlier et al., 2010; Goudeau et al., 2013).

Marine-derived OM is characterized by high TN contents yielding TN / OC ratio values $>0.12$, while vascular plants are N-depleted yielding TN / OC ratio values $<0.08$ (Redfield et al., 1963; Hedges and Oades, 1997). $\delta^{13} \mathrm{C}$ values in marine algae from low- to mid-latitude temperate seas vary from -18 to $-22 \%$ (Goericke and Fry, 1994; Meyers, 1994; Harmelin-Vivien et al., 2008), whereas most terrestrial OM inputs from $\mathrm{C} 3$ plants show depleted $\delta^{13} \mathrm{C}$ values ranging from -25 to $-28 \%$ (Hedges et al., 1997).

In order to constrain the origin of sedimentary OM and assess the spatial variability in its marine-to-terrestrial blend molar TN / OC ratios were plotted against $\delta^{13} \mathrm{C}$ values. Plots show that the elemental and isotopic composition of sedimentary OM fall out of the typical compositional ranges of the potential sources (Fig. 6b). Excluding station Red3, located in the upper slope of western Cretan Straits, an overall positive relationship for molar TN / OC ratios and $\delta^{13} \mathrm{C}$ values $(r=0.53, p<0.05)$ becomes apparent (Fig. 6b), thus indicating that the composition of the OM in the studied sediment samples could be explained as a mixture of terrigenous (low TN / OC and $\delta^{13} \mathrm{C}$ ) and marine-derived (high TN / OC and $\delta^{13} \mathrm{C}$ ) materials.

Additionally, the relative contribution of the marine vs. terrestrial sources of OC over the study area has been evaluated by means of a simple $\delta^{13} \mathrm{C}$-based binary mixing model (Table 2), where a marine $\delta^{13} \mathrm{C}$ value of $-20.4 \%$ and a terrestrial $\delta^{13} \mathrm{C}$ value of $-27.0 \%$ (Tesi et al., 2007a) are assumed, considering that the contribution of $\mathrm{C} 4$ vascular plants $\left(\delta^{13} \mathrm{C}\right.$ from -12 to $-15 \%$ ) can be considered negligible throughout the study area (e.g. Collatz et al., 1998).

As evident in Table 2, sediments from the Ionian Sea are characterized by elevated contributions of terrestrial OC $\left(\mathrm{OC}_{\text {terr }}\right)$, reaching up to $64.2 \%$. In contrast, W Cretan Straits, Cretan Sea and NW Levantine Sea stations show low OC contributions and marine $\mathrm{OC}\left(\mathrm{OC}_{\mathrm{mar}}\right)$ peaks of $87.7 \%$ (see also Sect. 5.2). The elevated $\mathrm{OC}_{\text {terr }}$ values recorded in the Ionian Sea suggest that terrigenous OM entering the Adriatic Sea escapes towards the deep Ionian basins. Indeed, during energetic dense shelf water cascading events, lateral flux prevails over the vertical flux in the southern Adriatic Sea and the contribution of soil-derived OC increases up to $\sim 60 \%$ (Turchetto et al., 2007; Tesi et al., 2008). Despite the relatively high $\mathrm{OC}_{\text {terr }}$ found preserved in the deep Ionian Sea, values are lower than those recorded in areas impacted by extreme events such as storms that enhance the export of organic matter from the shelf to the deep environment, for example in the western Mediterranean (up to $78 \%$ of $\mathrm{OC}_{\text {terr }}$ ) (Pedrosa-Pàmies et al., 2013) and the East China Sea (up to $90 \%$ ) (Selvaraj et al., 2015).

Lipid biomarkers have often been used as molecular proxies to identify specific biological precursors of sedimentary OM (Meyers, 1997; Volkman, 2006). The concentrations of the sedimentary lipid biomarkers determined in this study are 
fairly comparable to those previously reported in areas devoid of significant fluvial influence both in the eastern and western Mediterranean basins (Grimalt and Albaigés, 1990; Gogou et al., 2000; Gogou and Stephanou, 2004; Kaiser et al., 2014).

The patterns of long-chain $n$-alkanes and $n$-alkanols with elevated $\mathrm{CPI}_{\mathrm{NA}}$ and $\mathrm{CPI}_{\mathrm{N}-\mathrm{OH}}$ values (Sect. 4.4; Table 3) respectively indicate the presence of allochthonous natural (terrigenous) inputs from epicuticular higher plant waxes (Eglinton and Hamilton, 1967). Saharan dust is probably the main vector for the transport of small charcoal-like fragments of burnt vegetation, leaf wax-derived lipids absorbed on clays and cuticular fragments into the open EMS given the relatively minor direct influence of riverine inputs (Gogou et al., 1996; Eglinton et al., 2002).

Lipid biomarkers preserved in the surface sediments of the study area also highlight the contribution from autochthonous marine OM derived from in situ phytoplankton production. More specifically, the abundance of brassicasterol $\left(28 \Delta^{5,22 E}\right)$ reveals the presence of diatoms and prymnesiophytes, while dinosterol $\left(30 \Delta^{22 E}\right)$ is a major compound in dinoflagellates (Volkman, 1986). The presence of long-chain alkenones reflects the productivity from algal species of the Prymnesiophyte class, e.g. Emiliania huxleyii (Marlowe et al., 1984), which constitutes the dominant primary producers across the Mediterranean Sea (Ziveri et al., 2000; Triantaphyllou, 2004). Regarding the long-chain $\mathrm{C}_{30} n$-alkan-1,15-diols and the corresponding $\mathrm{C}_{30}$ keto-ols, although their major sources remain unknown, microalgae of the genus Nannochloropsis (class Eustigmatophyceae) are potential sources, while $\mathrm{C}_{30}$ keto-ols might result from oxidation of the corresponding $\mathrm{C}_{30}$ diols (Volkman, 1986; Volkman et al., 1999; Rampen et al., 2012).

In addition, while the abundance of cholesterol $\left(27 \Delta^{5}\right)$ highlights the existence of marine consumer organisms such as zooplankton and benthic animals (Grice et al., 1998), $\beta$ sitosterol $\left(29 \Delta^{5}\right)$ may derive from both terrigenous and marine sources (Volkman, 1986). In the study area, however, the positive correlation between $\sum$ TerNA (and $\sum$ TerN-OH) to $\beta$-sitosterol argues for a dominant terrestrial origin for this compound.

Aside from natural sources, the abundance of UCM indicates a contribution of anthropogenic OM resulting in chronic oil pollution of the investigated sediments (Parinos et al., 2013). UCM levels recorded in the deep EMS are comparable to those reported for surface sediments in unpolluted coastal and/or open-sea areas and are at least one order of magnitude lower than those reported for coastal areas subjected to enhanced anthropogenic inputs (Gogou et al., 2000; Parinos et al., 2013; Kaiser et al., 2014; Romero et al., 2015; and references therein). Two main pathways have been identified for the introduction of petroleum hydrocarbons into the deep EMS, which are direct discharges from merchant shipping and oil transportation (UNEP, 2010) and atmospheric transport and deposition (Gogou et al., 1996; Castro-Jiménez et al., 2012; Parinos et al., 2013).

\subsection{Regional variability and oceanographic control on the geochemical composition of deep eastern Mediterranean Sea surface sediments}

The PCA provides a robust overview of the variables and processes controlling the geochemical composition of the investigated deep-sea surface sediments (Fig. 5).

The significant positive loadings of $\sum$ TerNA, $\sum$ TerN$\mathrm{OH}, \sum \mathrm{Mar}$, UCM and depth on PC1 are indicative of a considerable contribution from both natural (marine and terrestrial) and anthropogenic (degraded petroleum products) OM preserved in deep-sea surface sediments of the EMS. Moreover, the negative $\mathrm{PC} 1$ loadings of $\mathrm{CPI}_{\mathrm{NA}}$ and $\mathrm{CPI}_{\mathrm{N}-\mathrm{OH}}$ ratios vs. depth indicate that the terrestrial OM is relatively altered with increasing water column depth. Although the negative $\mathrm{PC} 1$ loading of $\mathrm{CPI}_{\mathrm{NA}}$ ratio could be also indicative of an enhanced contribution from non-degraded petroleum inputs, the patterns of aliphatic hydrocarbons for the investigated sediment samples indicate no important bias associated to non-degraded petroleum products on $\mathrm{CPI}_{\mathrm{NA}}$ ratio values (Parinos et al., 2013). Overall, PC1 represents the degradation processes and fate of the sedimentary OM in the study area.

The second PC separates samples with high carbonate contents, molar TN / OC ratios and enhanced contribution of clay-sized particles from those with high lithogenic contents. Therefore, samples with positive loadings on PC2 are enriched in fine marine carbonate particles, while those with negative loadings are enriched in lithogenic particles (see Sect. 5.2.2).

Finally, PC3 separates samples with high contents of OC, $\mathrm{TN}$ and clays from those with high values of $\delta^{13} \mathrm{C}$. Consequently, positive loadings on PC3 are associated to sediments with an enhanced contribution of OC-rich fine particles, thus pointing to hydrodynamic processes that control grain size sorting and remobilization/deposition of sedimentary material with different OC contents (see Sect. 5.2.2).

\subsubsection{Processes modulating the biogeochemical signal of the sedimentary organic matter}

The low OC and TN contents in the surface sediments of the study area reflect the oligotrophic character of the EMS (e.g. Krom et al., 2003). In the studied sediments some processes may have further pushed TN to OC ratios towards low values (Fig. 6a). These include the preferential degradation of $\mathrm{N}$-rich proteinaceous components of algal OM during early diagenesis (Meyers et al., 1996; Meyers, 1997; Hopmans et al., 2004) and the enrichment of OC relative to TN due to the input of petroleum residues (Friligos et al., 1998). Furthermore, a significant contribution of inorganic N, presumably as $\mathrm{NH}_{4}^{+}$adsorbed on clays (Müller, 1977; Meyers, 1997), is 
inferred from the positive intercept on the $N$ axis at around $0.02 \%$ (Fig. 6a).

Although isotopic fractionation specifically associated with early diagenesis is negligible and the isotopic composition of sedimentary OM is fairly conservative (e.g. Di Leonardo et al., 2009 and references therein), $\delta^{13} \mathrm{C}$ values can be potentially shifted by microbial rearrangements (Lehmann et al., 2002) and inputs of anthropogenic OM. $\delta^{13} \mathrm{C}$ values for crude oil and petroleum products are in the order of -28.5 and $-28.9 \%$ respectively (Rumolo et al., 2011 and references therein). In the study area, the positive PC1 loadings of depth and UCM indicate an enhanced contribution of degraded petroleum products with increasing water depth. This points to an enrichment of the sediments in degraded petroleum hydrocarbons in the deep Ionian Sea and western Cretan Straits' stations H03 and Red3.1 where such an isotopic shift is observed (Figs. 3e and 7), in addition to maximum concentrations of UCM along with relatively low molar TN / OC ratios (<0.11) (Table 2, Figs. 3d and 4a).

Lipid biomarkers provide further information on the natural sources of sedimentary OM. The significant positive correlation of $\sum$ TerNA and $\sum$ TerN-OH concentrations (not normalized to $\mathrm{OC}$ ) to $\mathrm{OC}$ contents suggests a close association of terrestrial $\mathrm{OM}$ to $\mathrm{OC}$, while the significant positive correlation of $\sum$ TerNA and $\sum$ TerN-OH to $\%$ clay suggests that the transport and accumulation of terrestrial OM is associated to fine particles (see Sect. 5.2.2). The relatively uniform spatial distribution of $\mathrm{CPI}_{\mathrm{NA}}$ and $\mathrm{CPI}_{\mathrm{N}-\mathrm{OH}}$ ratio values (Fig. 8) together with the negative PC1 loadings of CPI $\mathrm{NA}$ and $\mathrm{CPI}_{\mathrm{N}-\mathrm{OH}}$ ratios vs. depth (Fig. 5), are overall indicative of the reworking of the terrestrial OM accumulated in deep EMS basins. Moreover, the elevated values of the [NA] / [N$\mathrm{OH}$ ] ratio in the study area (Fig. 8; Table 3) are indicative of the enhanced degradation of $\sum$ TerN-OH relatively to $\sum$ TerNA. The above are rather consistent with the longrange atmospheric transport and long residence time in the water column and into the sediments of the terrestrial OM and the fact that $\sum$ TerNA are more resistant to degradation than their alcohol counterparts (Gogou and Stephanou, 2004). Moreover, the relatively elevated retention time of terrestrial OC in the inner shelf of the Adriatic Sea, before being conveyed to the Ionian Sea by dense shelf water cascading events, allows for its significant microbial degradation or marine dilution (Tesi et al., 2008).

While a significant positive correlation is observed for $\sum$ Mar concentrations (not normalized to OC contents) and OC, indicating that the latter exerts an important control on the distribution of algal markers' concentrations in the study area, no significant correlation is observed between $\sum$ Mar and grain size. These correlations together with the deviation trend observed for molar TN / OC ratios from the classical Redfield ratio (16/106) with increasing water depth, which is more evident for the deep Ionian Sea stations (Fig. 6a), probably reflect the preferential degradation processes during the transport and deposition of marine labile sedimentary
OM, which probably also masks the association of marine $\mathrm{OM}$ to fine particles. The observations above, jointly with the presence of cholesterol $\left({ }_{27} \Delta^{5}\right)$ and its significant positive correlation with the concentrations of marine algal markers, are altogether indicative of the re-working of algal OM by zooplankton and benthic invertebrates (Volkman et al., 1990; Gogou and Stephanou, 2004).

\subsubsection{Sediment transport and deposition processes}

The second and third PCs of the PCA highlight the main processes that affect sediment dispersal and deposition in the study area. These relate to pelagic settling of marine skeletons from surface waters (corresponding to PC2) and hydrodynamic sorting of organic-rich fine sediment by bottom currents (corresponding to PC3).

Particulate matter exported from the upper layers of the water column in the EMS is primarily composed of biogenic particles and atmospheric dust, which while settling to the seabed are able to transfer OC, other nutrient elements and OC-associated organic pollutants (e.g. Stavrakakis et al., 2000, 2013; Theodosi et al., 2013). In the deep EMS, the distribution of pelagic carbonates (second PC) seems to be mainly influenced by planktonic contributions. In the study area, the phytoplankton biomass and primary production are relatively higher in regions of cyclonic water mass circulation. The Rhodes cold-core gyre, situated in the southeast of the Rhodes Island (NW Levantine Sea), is the most prominent dynamic feature in the EMS and is the main source area of the LIW. In this cyclonic gyre, which is enhanced during winter period, dense water masses from deeper layers tend to upwell at its centre, feeding the upper layers with nutrientrich waters (Salihoğlu et al., 1990). Therefore, this gyre plays an important role in the productivity of the Levantine Sea.

The third PC separated samples with high OC, TN and clay contents, which is indicative of a close OM-mineral association. This is in agreement with the high OC contents found in the fine-grained sediment samples from the deeper stations representing an essentially quiet environment (Figs. 2, 3 and 7). This is in contrast to the lower OC contents observed in coarser samples $\left(D_{50}>14 \mu \mathrm{m}\right)$ from shallower depths where currents up to $20 \mathrm{~cm} \mathrm{~s}^{-1}$ occur commonly (Kontoyiannis et al., 2005; Ursella et al., 2014). Finegrained particles have high capacity for OM adsorption due to their large specific surface area and thus enhanced OM contents relative to coarse-grained particles (Mayer, 1994; Hedges and Keil, 1995). Physical processes such as hydrodynamic sorting remobilize and transport sedimentary material with different $\mathrm{OC}$ contents, with the $\mathrm{OC}$-rich finest ones easily reaching the deep EMS. A similar situation has been reported in active sedimentary environments such as the submarine canyons in the western Mediterranean Sea (PedrosaPàmies et al., 2013), the northwestern Gulf of Mexico (Goñi et al., 1998) and the Peru Margin (Bergamaschi et al., 1997). However, none of these studies reported such OM-mineral 


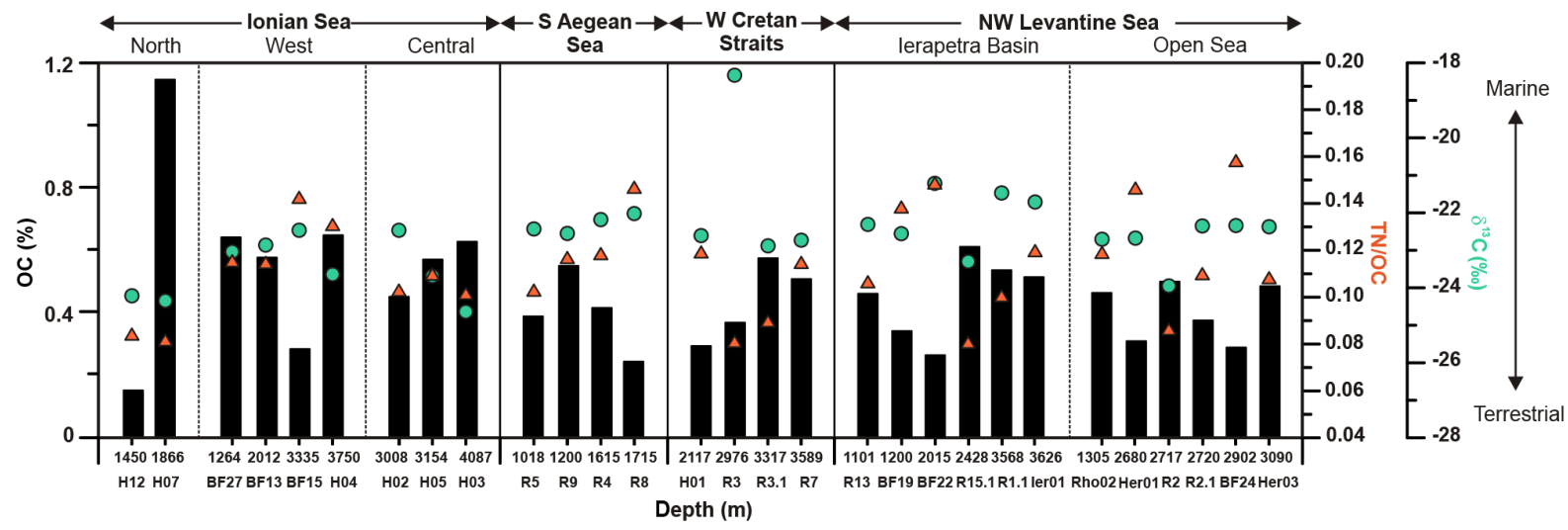

Figure 7. Distribution of OC content and bulk sediment tracers (TN / OC and $\delta^{13} \mathrm{C}$ ) in surface sediments of the deep eastern Mediterranean Sea. The histogram reflects a spatially variable mixture of marine and terrestrial sources for sedimentary OM. Orange triangles and green circles correspond to molar TN / OC ratios and $\delta^{13} \mathrm{C}$ values respectively.

associations at depths beyond $4000 \mathrm{~m}$. This indicates that this organic-mineral interaction is maintained from the shallow to high depths, which constitute the final sedimentary sink. In short, the deep EMS behaves as a depocentre for OM-rich fine particles.

Moreover, in the EMS these bulk sediments show a poorer sorting than the lithogenic fraction (Fig. 2). This could be related to the presence of coarse biogenic carbonate particles in bulk samples or the effective hydrodynamic sorting linked to the prevailing depositional conditions in such deep lowenergy environments (Friedman, 1969).

The poor sorting and positive skewness found in grain size types I, II, IV and V of the bulk sediment samples (Fig. 2a) in the southern Aegean Sea and the northwestern Levantine Sea are explained by the prevalence of pelagic biogenic sedimentation, as shown by the high positive score values observed on PC2 (Fig. 5b). Accordingly, high percentages of $\mathrm{CaCO}_{3}$ have been measured in stations of the southern Aegean Sea, the northwestern Levantine Sea and western Cretan Straits, which correlate to \% clay fraction of the bulk sediment samples and the concentrations of alkenones (Table 3). This links to the formation of clay-carbonate concretions that have been reported in particularly large amounts in the southern Aegean Sea (Emelyanov and Shimkus, 1986). Vertical mixing and upward transport of nutrients in the eddies and gyres, such as the Rhodes gyre, may trigger primary production and subsequently the sinking and dominance of pelagic biogenic particles over particles from other sources in the northwestern Levantine Sea (Siokou-Frangou et al., 1999). The $\% \mathrm{OC}_{\mathrm{mar}}$ and the $\sum$ Mar distribution are indicative in that respect as they show a general eastward increasing trend with peak concentrations in deep basins of the northwestern Levantine Sea.

Surface sediments in the Ierapetra Basin (stations Red15, Red1.1 and Ier01) also show positive scores on PC3 (Fig. 5b), which point to an influence of hydrodynamic sort- ing processes. The relatively high OC content in these stations (Fig. 7), along with the elevated values of the associated natural and anthropogenic lipid concentrations (Table 3), suggests that the Hellenic Trench is a sink of OC associated to fine particles transferred by the active outflows of the Cretan Straits, besides the pelagic sedimentation related to the well-known semi-permanent Ierapetra anticyclone (Larnicol et al., 2002; Taupier-Letage, 2008).

Sediments with grain size types I-III of the bulk sediment samples (Fig. 2a) in the Ionian Sea show lower $\mathrm{CaCO}_{3}$ contents due to the dilution by lithogenic components, with station $\mathrm{H} 02$ being the only exception. High positive score values on PC3 (Fig. 5b), and the significant positive correlation for $\mathrm{OC}$ and $\mathrm{TN}$ contents to \% clay of the lithogenic fraction, further suggest a significant influence of hydrodynamic sorting processes, which largely determine a differential distribution of OM in surface sediments according to grain size. In this area, the Otranto Strait may act as a preferential conduit by funnelling fine OC-rich particles from the Adriatic Sea towards the deep basins of the adjacent Ionian Sea, which may eventually reach the Levantine Sea (Bensi et al., 2013). The enhanced contributions of $\mathrm{OC}_{\text {terr }}$ (Table 2) and terrestrial biomarkers concentrations (Figs. $4 \mathrm{~b}-\mathrm{c}$ and Table 3 ) of the Ionian samples off the southern mouth of the Adriatic Sea probably also reflect the preferential degradation of labile marine OM in deep Ionian Sea basins due to slower sedimentation rates and longer residence time of OM. Low OC content (Fig. 3c), poor sorting and very negatively skewed high \% sand of grain size type VI (Fig. 2a) at the shallower station $\mathrm{H} 12$ just south of Otranto Strait support winnowing of fine OC-rich particles due to episodic events of high current speed exiting the Adriatic Sea (Bignami et al., 1991; Gacic et al., 1996; Poulos et al., 1999).

Finally, station Red3 from the upper slope of western Cretan Straits representing grain size type VII of the bulk sediment samples (Fig. 2a) shows the highest contents of sand 
$[\mathrm{NA}] /[\mathrm{N}-\mathrm{OH}]$
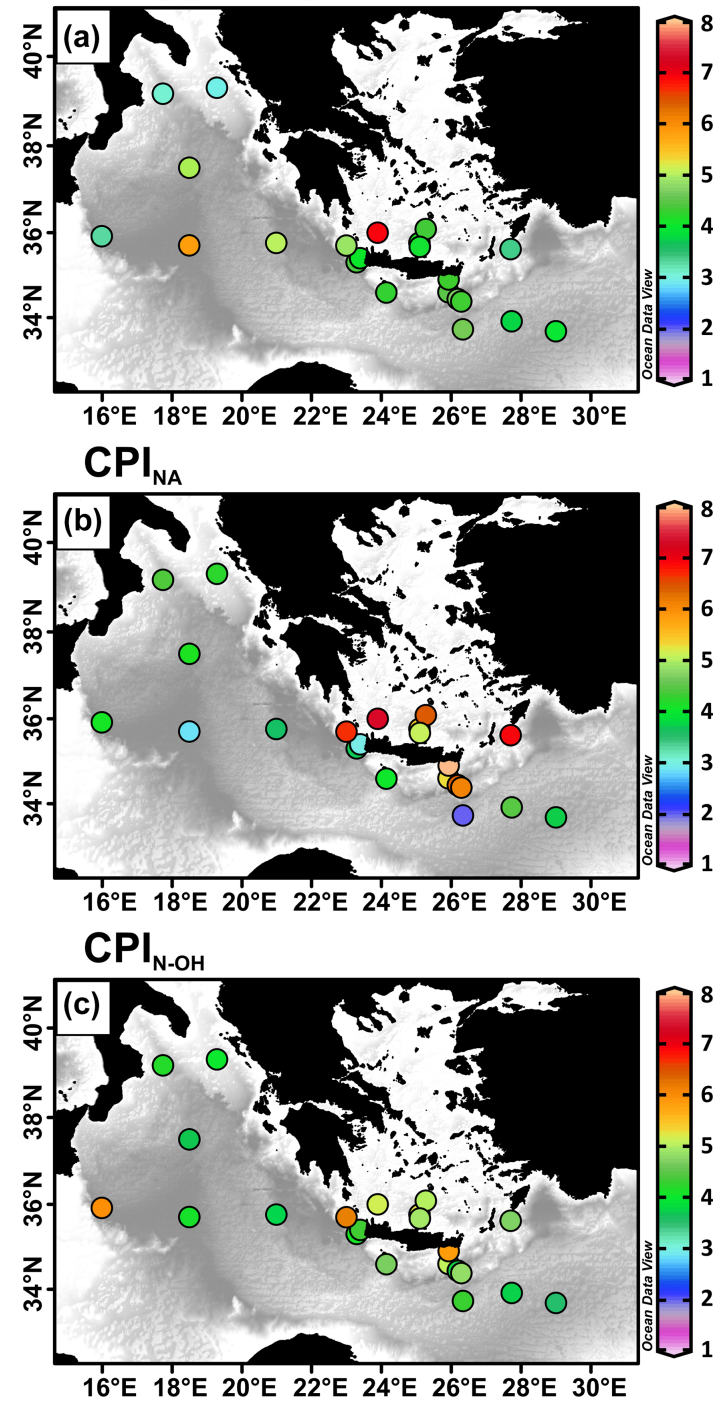

Figure 8. Spatial distribution of lipid biomarker indices (a) $[\mathrm{NA}] /[\mathrm{N}-\mathrm{OH}]$, (b) $\mathrm{CPI}_{\mathrm{NA}}$ and (c) $\mathrm{CPI}_{\mathrm{N}-\mathrm{OH}}$. Abbreviations of lipid biomarker indices are defined in the text.

$(47.7 \%)$, which is poorly sorted. This is in agreement with the occurrence of the topographically restricted deep outflow of the western Cretan Straits. These straits are characterized by maximum outflow speeds during winter and minimum speeds during fall (Kontoyiannis et al., 2005). The turbulent, fluctuating outflow current should normally trigger sediment resuspension and induce selective transport, thus leaving coarse OC-poor particles in the upper slope of the western Cretan Straits (negative factor scores of PC2 and PC3) and carrying fine OC-rich particles to the lower slope. A similar pattern has been also observed in other submarine canyon settings of the Mediterranean Sea, such as the Cap de Creus Canyon (Sanchez-Vidal et al., 2008) and the Blanes Canyon (Pedrosa-Pàmies et al., 2013). The top $\delta^{13} \mathrm{C}$ values found in the upper slope (Fig. 7 and Tables 2-3) indicates high contribution of marine OC, which, however, is not supported by the lipid biomarkers results. Winnowing of fine particles loaded with terrestrial OC, thus shifting the isotopic signal of the remaining coarse particles towards high and more marine values seems to be the most plausible explanation.

\section{Conclusions}

Surface sediments collected from deep basins of the oligotrophic EMS were investigated using a multi-proxy approach that involved elemental composition, grain size, stable isotopes and selected lipid biomarkers' analyses resulting in a robust database to determine sediment sources, the degradation and preservation state of $\mathrm{OM}$ and processes that affect sediment dispersal and deposition. The PCA analysis helped to identify the main controlling factors of the observed geochemical variability in the investigated sediments. Such factors are sediment sources in terms of allochthonous vs. autochthonous, a highly variable physiography, the thermohaline structure and the regional and local circulation, leading to hydrodynamic sorting and regulating particle settling/deposition and OM preservation state.

Surface sediments of the investigated part of the EMS mostly consist of airborne lithogenic particles and biogenic carbonate particles, the latter deriving from primary production into surface waters. Sedimentary OM appears in rather low contents $(0.15-1.15 \%$ OC), with bulk and molecular organic tracers reflecting a mixed contribution from both natural (autochthonous and allochthonous) and anthropogenic sources. Samples from locations in the Ionian Sea and the western Cretan Straits that are under the direct influence of the Adriatic dense waters outflow through the Otranto Strait and of currents exiting the southern Aegean Sea respectively are appreciably sorted. Current regime impacted not only grain size but also OC loadings within each subregion of the study area, with winnowing of fine OC-rich particles to the deepest EMS. In contrast, coarse OC-poor particles tend to occur in upper slope settings. While OC associated to fine particles was relatively non-degraded terrestrial $\mathrm{OM}$, marine OM was found to be mostly degraded and reworked during transport processes and before reaching the deep seafloor.

The spatial variability in the yields of sedimentary OC and lipid biomarkers presented in this study highlights the heterogeneous nature of the particle load exported to the deep basins of the eastern Mediterranean Sea. Such variability must be taken into account during the development of quantitative carbon budgets for this area. 
Acknowledgements. This research has been supported by the EU-funded project PERSEUS (GA 287600), the EU-Greek co-funded project KRIPIS (MIS 451724; NSRF) and REDECO (CTM2008-04973-E/MAR), BIOFUN (CTM2007-28739-E) and

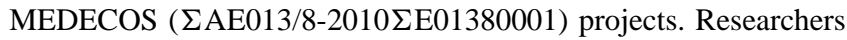
from GRC Geociències Marines benefited from a Grups de Recerca Consolidats grant 2014 SGR 1068 by the Generalitat de Catalunya autonomous government. We sincerely thank chief scientist K. C. Emeis (R/V Meteor) and the officers and crews of R/V Meteor, R/V Aegaeo and R/V Sarmiento de Gamboa for their precious help during the cruises. Elemental and isotopic analyses have been performed at the scientific-technical services of the University of Barcelona. R. Pedrosa-Pàmies is supported by a predoctoral FPU grant and A. Sanchez-Vidal by a Ramon y Cajal contract. Juergen Mobius is acknowledged for his constructive comments on an earlier version of the manuscript. We would like to thank the editor, T. Tesi and three anonymous referees for their constructive comments that helped us significantly improve the quality of the manuscript during the revision process.

Edited by: G. Herndl

\section{References}

Amblàs, D., Canals, M., Lastras, G., Berné, S., and Loubrieu, B.: Imaging the Seascapes of the Mediterranean, Oceanography, 17, 144-155, doi:10.5670/oceanog.2004.11, 2004.

Bensi, M., Cardin, V., Rubino, A., Notarstefano, G., and Poulain, P. M.: Effects of winter convection on the deep layer of the Southern Adriatic Sea in 2012, J. Geophys. Res.-Oceans, 118, 6064-6075, doi:10.1002/2013JC009432, 2013.

Bergamaschi, B. A., Tsamakis, E., Keil, R. G., Eglinton, T. I., Montluçon, D. B., and Hedges, J. I.: The effect of grain size and surface area on organic matter, lignin and carbohydrate concentration, and molecular compositions in Peru Margin sediments, Geochim. Cosmochim. Acta, 61, 1247-1260, doi:10.1016/S0016-7037(96)00394-8, 1997.

Bethoux, J. P.: Budgets of the Mediterranean Sea. Their dependence on the local climate and on the characteristics of the Atlantic waters, Oceanol. Acta, 2, 157-163, 1979.

Bethoux, J. P.: Oxygen consumption, new production, vertical advection and environmental evolution in the Mediterranean Sea, Deep-Sea Res., 36, 769-781, doi:10.1016/0198-0149(89)901507, 1989.

Bianchi, A., Tholosan, O., Garcin, J., Polychronaki, T., Tselepides, A., Buscail, R., and Duineveld, G.: Microbial activities at the benthic boundary layer in the Aegean Sea, Prog. Oceanogr., 57, 219-236, doi:10.1016/S0079-6611(03)00034-X, 2003.

Blott, S. J. and Pye, K.: GRADISTAT: a grain size distribution and statistics package for the analysis of unconsolidated sediments, Earth Surf. Proc. Land., 26, 1237-1248, doi:10.1002/esp.261, 2001.

Bosc, E., Bricaud, A., and Antoine, D.: Seasonal and interannual variability in algal biomass and primary production in the Mediterranean Sea, as derived from 4 years of SeaWiFS observations, Global Biogeochem. Cy., 18, GB1005, doi:10.1029/2003GB002034, 2004.
Bouloubassi, I., Lipiatou, E., Saliot, A., Tolosa, I., Bayona, J. M., and Albaigés, J.: Carbon sources and cycle in the western Mediterranean-the use of molecular markers to determine the origin of organic matter, Deep-Sea Res. Pt. II, 44, 781-799, doi:10.1016/S0967-0645(96)00094-X, 1997.

Burdige, D. J.: Preservation of organic matter in marine sediments: controls, mechanisms, and an imbalance in sediment organic carbon budgets?, Chem. Rev., 107, 467-485, doi:10.1021/cr050347q, 2007.

Canals, M., Danovaro, R., Heussner, S., Lykousis, V., Puig, P., Trincardi, F., Calafat, A., Durrieu de Madron, X., and Palanques, A.: Cascades in Mediterranean Submarine Grand Canyons, Oceanography, 22, 26-43, doi:10.5670/oceanog.2009.03, 2009.

Carlier, A., Ritt, B., Rodrigues, C. F., Sarrazin, J., Olu, K., Grall, J., and Clavier, J.: Heterogeneous energetic pathways and carbon sources on deep eastern Mediterranean cold seep communities, Mar. Biol., 157, 2545-2565, doi:10.1007/s00227-010-1518-1, 2010.

Castro-Jiménez, J., Berrojalbiz, N., Wollgast, J., and Dachs, J.: Polycyclic Aromatic Hydrocarbons (PAHs) in the Mediterranean Sea: atmospheric occurrence, deposition and decoupling with settling fluxes in the water column, Environ. Pollut., 166, 40-47, doi:10.1016/j.envpol.2012.03.003, 2012.

Chester, R., Baxter, G. G., Behairy, A. K. A., Connor, K., Cross, D., Elderfield, H., and Padgham, R. C.: Soil-sized eolian dusts from the lower troposphere of the eastern Mediterranean Sea, Mar. Geol., 24, 201-217, doi:10.1016/0025-3227(77)90028-7, 1977.

Collatz, G. J., Berry, J. a., and Clark, J. S.: Effects of climate and atmospheric $\mathrm{CO}_{2}$ partial pressure on the global distribution of $\mathrm{C}_{4}$ grasses: present, past, and future, Oecologia, 114, 441-454, doi:10.1007/s004420050468, 1998.

Collister, J. W., Rieley, G., Stern, B., Eglinton, G., and Fry, B.: Compound-specific $\delta 13 \mathrm{C}$ analyses of leaf lipids from plants with differing carbon dioxide metabolisms, Org. Geochem., 21, 619627, doi:10.1016/0146-6380(94)90008-6, 1994.

Correggiari, A., Guerzoni, S., Lenaz, R., Quarantotto, G., and Rampazzo, G.: Dust deposition in the central Mediterranean (Tyrrhenian and Adriatic Seas): relationships with marine sediments and riverine input, Terra Nova, 1, 549-558, doi:10.1111/j.13653121.1989.tb00431.x, 1989.

Cros, L.: Calcareous nannoplankton in surficial sediments of the Catalano-Balearic Sea (northeastern Mediterranean), in: 5th INA Conference in Salamanca Proceedings, 47-59, 1995.

Danovaro, R., Company, J. B., Corinaldesi, C., D’Onghia, G., Galil, B., Gambi, C., Gooday, A. J., Lampadariou, N., Luna, G. M., Morigi, C., Olu, K., Polymenakou, P. N., RamirezLlodra, E., Sabbatini, A., Sardà, F., Sibuet, M., and Tselepides, A.: Deep-sea biodiversity in the Mediterranean Sea: the known, the unknown, and the unknowable, PLoS One, 5, e11832, doi:10.1371/journal.pone.0011832, 2010.

Danovaro, R., Company, J. B., Corinaldesi, C., D’Onghia, G., Galil, B., Gambi, C., Gooday, A. J., Lampadariou, N., Luna, G. M., Morigi, C., Olu, K., Polymenakou, P. N., RamirezLlodra, E., Sabbatini, A., Sardà, F., Sibuet, M. and Tselepides, A.: Deep-sea biodiversity in the Mediterranean Sea: the known, the unknown, and the unknowable., PLoS One, 5, e11832, doi:10.1371/journal.pone.0011832, 2010.

Di Leonardo, R., Vizzini, S., Bellanca, A., and Mazzola, A.: Sedimentary record of anthropogenic contaminants (trace met- 
als and PAHs) and organic matter in a Mediterranean coastal area (Gulf of Palermo, Italy), J. Marine Syst., 78, 136-145, doi:10.1016/j.jmarsys.2009.04.004, 2009.

Durrieu de Madron, X., Abassi, A., Heussner, S., Monaco, A., Aloisi, J. C., Radakovitch, O., Giresse, P., Buscail, R., and Kerherve, P.: Particulate matter and organic carbon budgets for the Gulf of Lions (NW Mediterranean), Oceanol. Acta, 23, 717-730, doi:10.1016/S0399-1784(00)00119-5, 2000.

Eglinton, G. and Hamilton, R. J.: Leaf epicuticular waxes, Science, 156, 1322-1335, doi:10.1126/science.156.3780.1322, 1967.

Eglinton, T. I., Eglinton, G., Dupont, L., Sholkovitz, E. R., Montluçon, D., and Reddy, C. M.: Composition, age, and provenance of organic matter in NW African dust over the Atlantic Ocean, Geochemistry, Geophys. Geosystems, 3, 1-27, 2002.

Ehrmann, W., Schmiedl, G., Hamann, Y., Kuhnt, T., Hemleben, C., and Siebel, W.: Clay minerals in late glacial and Holocene sediments of the northern and southern Aegean Sea, Palaeogeogr. Palaeocl., 249, 36-57, doi:10.1016/j.palaeo.2007.01.004, 2007.

Emelyanov, E. M. and Shimkus, K. M.: Geochemistry and Sedimentology of the Mediterranean Sea, D. Reidel Publishing Company, Dordrecht, the Netherlands, 1986.

Folk, R. L. and Ward, W. C.: Brazos River bar: a study in the significance of grain size parameters, J. Sediment. Res., 27, 3-26, doi:10.1306/74D70646-2B21-11D78648000102C1865D, 1957.

Frenz, M., Baumann, K. H., Boeckel, B., Hoppner, R., and Henrich, R.: Quantification of foraminifer and coccolith carbonate in South Atlantic surface sediments by means of carbonate grain-size distributions, J. Sediment. Res., 75, 464-475, doi:10.2110/jsr.2005.036, 2005.

Friedman, G. M.: Trace elements as possible environmental indicators in carbonate sediments, in: Depos. Environ. Carbonate Rocks, 193-198, 1969.

Friligos, N., Moriki, A., Sklivagou, E., Krasakopoulou, E., and Hatzianestis, I.: Geochemical characteristics of the surficial sediments of the Aegean Sea, in: 3rd MTP-MATER Workshop, Rhodos, vol. 35, 28-209, 1998.

Garcia-Orellana, J., Pates, J. M., Masqué, P., Bruach, J. M., and Sanchez-Cabeza, J. A.: Distribution of artificial radionuclides in deep sediments of the Mediterranean Sea, Sci. Total Environ., 407, 887-898, doi:10.1016/j.scitotenv.2008.09.018, 2009.

Goericke, R. and Fry, B.: Variations of marine plankton $\delta^{13} \mathrm{C}$ with latitude, temperature, and dissolved $\mathrm{CO}_{2}$ in the world ocean, Global Biogeochem. Cy., 8, 85-90, doi:10.1029/93GB03272, 1994.

Gogou, A. and Stephanou, E. G.: Marine organic geochemistry of the Eastern Mediterranean, Mar. Chem., 85, 1-25, doi:10.1016/j.marchem.2003.08.005, 2004.

Gogou, A., Stratigakis, N., Kanakidou, M., and Stephanou, E. G.: Organic aerosols in Eastern Mediterranean: components source reconciliation by using molecular markers and atmospheric back trajectories, Org. Geochem., 25, 79-96, doi:10.1016/S01466380(96)00105-2, 1996.

Gogou, A., Apostolaki, M., and Stephanou, E. G.: Determination of organic molecular markers in marine aerosols and sediments: one-step flash chromatography compound class fractionation and capillary gas chromatographic analysis, J. Chromatogr. A, 799, 215-231, doi:10.1016/S0021-9673(97)01106-0, 1998.
Gogou, A., Bouloubassi, I., and Stephanou, E. G.: Marine organic geochemistry of the Eastern Mediterranean: 1. aliphatic and polyaromatic hydrocarbons in Cretan Sea surficial sediments, Mar. Chem., 68, 265-282, doi:10.1016/S0304-4203(99)00082$1,2000$.

Gogou, A., Bouloubassi, I., Lykousis, V., Arnaboldi, M., Gaitani, P., and Meyers, P. A.: Organic geochemical evidence of Late Glacial-Holocene climate instability in the North Aegean Sea, Palaeogeogr. Palaeocl., 256, 1-20, doi:10.1016/j.palaeo.2007.08.002, 2007.

Gogou, A., Sanchez-Vidal, A., Durrieu de Madron, X., Stavrakakis, S., Calafat, A., Stabholz, M., Psarra, S., Canals, M., Heussner, S., Stavrakaki, I., and Papathanassiou, E.: Carbon flux to the deep in three open sites of the Southern European Seas (SES), J. Marine Syst., 129, 224-233, doi:10.1016/j.jmarsys.2013.05.013, 2014.

Goñi, M. A., Ruttenberg, K. C., and Eglinton, T. I.: A reassessment of the sources and importance of land-derived organic matter in surface sediments from the Gulf of Mexico, Geochim. Cosmochim. Ac., 62, 3055-3075, doi:10.1016/S00167037(98)00217-8, 1998.

Goñi, M. A., Teixeira, M. J., and Perkey, D. W.: Sources and distribution of organic matter in a river-dominated estuary (Winyah Bay, SC, USA), Estuar. Coast. Shelf S., 57, 1023-1048, doi:10.1016/S0272-7714(03)00008-8, 2003.

Goñi, M. A., Monacci, N., Gisewhite, R., Ogston, A., Crockett, J., and Nittrouer, C.: Distribution and sources of particulate organic matter in the water column and sediments of the Fly River Delta, Gulf of Papua (Papua New Guinea), Estuar. Coast. Shelf S., 69, 225-245, doi:10.1016/j.ecss.2006.04.012, 2006.

Goudeau, M.-L. S., Grauel, A.-L., Bernasconi, S. M., and de Lange, G. J.: Provenance of surface sediments along the southeastern Adriatic coast off Italy: an overview, Estuar. Coast. Shelf S., 134, 45-56, doi:10.1016/j.ecss.2013.09.009, 2013.

Gough, M. A. and Rowland, S. J.: Characterization of unresolved complex mixtures of hydrocarbons in petroleum, Nature, 344, 648-650, doi:10.1038/344648a0, 1990.

Grice, K., Klein Breteler, W., Schouten, S., Grossi, V., Leeuw, J. W., and Damsté, J. S. S.: Effects of zooplankton herbivory on biomarker proxy records, Paleoceanography, 13, 686-693, doi:10.1029/98PA01871, 1998.

Grimalt, J. O. and Albaigés, J.: Characterization of the depositional environments of the Ebro Delta (western Mediterranean) by the study of sedimentary lipid markers, Mar. Geol., 95, 207-224, doi:10.1016/0025-3227(90)90117-3, 1990.

Guerzoni, S. and Molinaroli, E.: Input of various chemicals transported by Saharan dust and depositing at the sea surface in the Mediterranean Sea, Environ. Chem., 5, 237-268, doi:10.1007/b107149, 2005.

Guerzoni, S., Chester, R., Dulac, F., Herut, B., Loÿe-Pilot, M.-D., Measures, C., Migon, C., Molinaroli, E., Moulin, C., Rossini, P., Saydam, C., Soudine, A., and Ziveri, P.: The role of atmospheric deposition in the biogeochemistry of the Mediterranean Sea, Prog. Oceanogr., 44, 147-190, doi:10.1016/S00796611(99)00024-5, 1999.

Hamann, Y., Ehrmann, W., Schmiedl, G., Krüger, S., Stuut, J.B., and Kuhnt, T.: Sedimentation processes in the Eastern Mediterranean Sea during the Late Glacial and Holocene revealed by end-member modelling of the terrigenous 
fraction in marine sediments, Mar. Geol., 248, 97-114, doi:10.1016/j.margeo.2007.10.009, 2008.

Harmelin-Vivien, M., Loizeau, V., Mellon, C., and Beker, B.: Comparison of $\mathrm{C}$ and $\mathrm{N}$ stable isotope ratios between surface particulate organic matter and microphytoplankton in the Gulf of Lions (NW Mediterranean), Cont. Shelf Res., 28, 1911-1919, doi:10.1016/j.csr.2008.03.002, 2008.

Hedges, J. I. and Keil, R. G.: Sedimentary organic matter preservation: an assessment and speculative synthesis, Mar. Chem., 49, 81-115, doi:10.1016/0304-4203(95)00008-F, 1995.

Hedges, J. I. and Oades, J. M.: Comparative organic geochemistries of soils and marine sediments, Org. Geochem., 27, 319-361, doi:10.1016/S0146-6380(97)00056-9, 1997.

Hedges, J. I., Keil, R. G., and Benner, R.: What happens to terrestrial organic matter in the ocean?, Org. Geochem., 27, 195-212, doi:10.1016/S0146-6380(97)00066-1, 1997.

Heussner, S., Calafat, A., and Palanques, A.: Quantitative and qualitative features of particle fluxes in the North-Balearic Basin, in: EUROMARGE-NB Final Report, edited by: Canals, M., Casamor, J. L., Cacho, I., Calafat, A. M., Monaco, A., MAST II Program, EC, 2, 41-66, 1996.

Hopmans, E. C., Weijers, J. W.., Schefuß, E., Herfort, L., Sinninghe Damsté, J. S., and Schouten, S.: A novel proxy for terrestrial organic matter in sediments based on branched and isoprenoid tetraether lipids, Earth Planet. Sc. Lett., 224, 107-116, doi:10.1016/j.eps1.2004.05.012, 2004.

Hu, J., Peng, P., Jia, G., Mai, B., and Zhang, G.: Distribution and sources of organic carbon, nitrogen and their isotopes in sediments of the subtropical Pearl River estuary and adjacent shelf, Southern China, Mar. Chem., 98, 274-285, doi:10.1016/j.marchem.2005.03.008, 2006.

IOC, IHO and BODC: Centenary edition of the GEBCO digital atlas, published on CD-ROM on behalf of the Intergovernmental Oceanographic Commission and the International Hydrographic Organization as part of the General Bathymetric Chart of the Oceans, Liverpool, UK, 2003.

Jickells, T. D.: Atmospheric inputs of metals and nutrients to the oceans: their magnitude and effects, Mar. Chem., 48, 199-214, doi:10.1016/0304-4203(95)92784-P, 1995.

Jickells, T. D., An, Z. S., Andersen, K. K., Baker, A. R., Bergametti, G., Brooks, N., Cao, J. J., Boyd, P. W., Duce, R. A., Hunter, K. A., Kawahata, H., Kubilay, N., laRoche, J., Liss, P. S., Mahowald, N., Prospero, J. M., Ridgwell, A. J., Tegen, I., and Torres, R.: Global iron connections between desert dust, ocean biogeochemistry, and climate, Science, 308, 67-71, doi:10.1126/science.1105959, 2005.

Kaiser, J., Ruggieri, N., Hefter, J., Siegel, H., Mollenhauer, G., Arz, H. W., and Lamy, F.: Lipid biomarkers in surface sediments from the gulf of genoa, Ligurian sea (NW Mediterranean sea) and their potential for the reconstruction of palaeo-environments, Deep-Sea Res. Pt. I, 89, 68-83, doi:10.1016/j.dsr.2014.04.009, 2014.

Kelepertsis, A. E., Alexakis, D. E., Nastos, P. T., and Kanellopoulou, E. A.: The presence of volcanic ash in the western Greece and its association with the eruption of the Etna volcano, Italy, consequences on the environment, in: 8th International Conference on Environmantal Science and Technology, Lemnos Island, Greece, 408-415, 2003.
Kemp, A. E. S., Pearce, R. B., Koizumi, I., Pike, J., and Rance, S. J.: The role of mat-forming diatoms in the formation of Mediterranean sapropels, Nature, 398, 57-61, doi:10.1038/18001, 1999.

Kontoyiannis, H., Balopoulos, E., Gotsis-Skretas, O., Pavlidou, A., Assimakopoulou, G., and Papageorgiou, E.: The hydrology and biochemistry of the Cretan Straits (Antikithira and Kassos Straits) revisited in the period June 1997-May 1998, J. Marine Syst., 53, 37-57, doi:10.1016/j.jmarsys.2004.06.007, 2005.

Krom, M. D., Groom, S., and Zohary, T.: The Eastern Mediterranean, the Biogeo., edited by: Black, G. B. and Shimmield, K. D., Blackwell Publishing, Oxford, 91-122, 2003.

Krom, M. D., Woodward, E. M. S., Herut, B., Kress, N., Carbo, P., Mantoura, R. F. C., Spyres, G., Thingstad, T. F., Wassmann, P., Wexels-Riser, C., Kitidis, V., Law, C. S., and Zodiatis, G.: Nutrient cycling in the south east Levantine basin of the eastern Mediterranean: results from a phosphorus starved system, DeepSea Res. Pt. II, 52, 2879-2896, doi:10.1016/j.dsr2.2005.08.009, 2005.

Larnicol, G., Ayoub, N., and Le Traon, P. Y.: Major changes in Mediterranean Sea level variability from 7 years of TOPEX/Poseidon and ERS-1/2 data, J. Marine Syst., 33-34, 6389, doi:10.1016/S0924-7963(02)00053-2, 2002.

Lascaratos, A., Williams, R. G., and Tragou, E.: A mixed-layer study of the formation of Levantine intermediate water, J. Geophys. Res., 98, 14739, doi:10.1029/93JC00912, 1993.

Lascaratos, A., Roether, W., Nittis, K., and Klein, B.: Recent changes in deep water formation and spreading in the eastern Mediterranean Sea: a review, Prog. Oceanogr., 44, 5-36, doi:10.1016/S0079-6611(99)00019-1, 1999.

Lutz, M., Dunbar, R., and Caldeira, K.: Regional variability in the vertical flux of particulate organic carbon in the ocean interior, Global Biogeochem. Cy., 16, 11-1-11-18, doi:10.1029/2000GB001383, 2002.

Malanotte-Rizzoli, P. and Hecht, A.: Large-scale properties of the eastern mediterranean-A review, Oceanol. Acta, 11(4), 323-335, 1988.

Malanotte-Rizzoli, P., Manca, B. B., Alcala, M. R. D., Bergamasco, A., Bregant, D., and Georgopoulos, D.: A synthesis of the Ionian Sea hydrography, circulation and water mass pathways during POEM-Phase I, Prog. Oceanogr., 39, 153-204, doi:10.1016/S0079-6611(97)00013-X, 1997.

Manca, B. B., Kovacević, V., Gacić, M., and Viezzoli, D.: Dense water formation in the Southern Adriatic Sea and spreading into the Ionian Sea in the period 1997-1999, J. Mar. Syst., 33-34, 133-154, doi:10.1016/S0924-7963(02)00056-8, 2002.

Marlowe, I. T., Green, J. C., Neal, A. C., Brassell, S. C., Eglinton, G., and Course, P. A.: Long chain (n-C37-C39) alkenones in the Prymnesiophyceae. Distribution of alkenones and other lipids and their taxonomic significance, Brit. Phycol. J., 19, 203-216, doi:10.1080/00071618400650221, 1984.

Masqué, P., Fabres, J., Canals, M., Sanchez-Cabeza, J. A., SanchezVidal, A., Cacho, I., Calafat, A., and Bruach, J. M.: Accumulation rates of major constituents of hemipelagic sediments in the deep Alboran Sea: a centennial perspective of sedimentary dynamics, Mar. Geol., 193, 207-233, doi:10.1016/S00253227(02)00593-5, 2003.

Mayer, L. M.: Relationships between mineral surfaces and organic carbon concentrations in soils and sediments, Chem. Geol., 114, 347-363, doi:10.1016/0009-2541(94)90063-9, 1994. 
Meador, T. B., Gogou, A., Spyres, G., Herndl, G. J., Krasakopoulou, E., Psarra, S., Yokokawa, T., De Corte, D., Zervakis, V., and Repeta, D. J.: Biogeochemical relationships between ultrafiltered dissolved organic matter and picoplankton activity in the Eastern Mediterranean Sea, Deep-Sea Res. Pt. II, 57, 1460-1477, doi:10.1016/j.dsr2.2010.02.015, 2010.

Medimap Group: Morpho-bathymetry of the Mediterranean Sea, E: $1=2000$ 000, CIESM/Ifremer Sp. Publ., Maps and Atlases, two maps (Western Mediterranean and Eastern Mediterranean), Montecarlo/Brest, Monaco/France, 2007.

Meyers, P. A.: Preservation of elemental and isotopic source identification of sedimentary organic matter, Chem. Geol., 114, 289302, doi:10.1016/0009-2541(94)90059-0, 1994.

Meyers, P. A.: Organic geochemical proxies of paleoceanographic, paleolimnologic, and paleoclimatic processes, Org. Geochem., 27, 213-250, doi:10.1016/S0146-6380(97)00049-1, 1997.

Meyers, P. A. and Arnaboldi, M.: Paleoceanographic implications of nitrogen and organic carbon isotopic excursions in mid-Pleistocene sapropels from the Tyrrhenian and Levantine Basins, Mediterranean Sea, Palaeogeogr. Palaeocl., 266, 112118, doi:10.1016/j.palaeo.2008.03.018, 2008.

Meyers, P. A., Silliman, J. E., and Shaw, T. J.: Effects of turbidity flows on organic matter accumulation, sulfate reduction, and methane generation in deep-sea sediments on the Iberia Abyssal Plain, Org. Geochem., 25, 69-78, doi:10.1016/S01466380(96)00106-4, 1996

Milliff, R. F. and Robinson, A. R.: Structure and dynamics of the Rhodes gyre system and dynamical interpolation for estimates of the mesoscale variability, J. Phys. Oceanogr., 22, 317-337, doi:10.1175/1520-0485(1992)022<0317:SADOTR>2.0.CO;2, 1992.

Millot, C. and Taupier-Letage, I.: Additional evidence of LIW entrainment across the Algerian subbasin by mesoscale eddies and not by a permanent westward flow, Prog. Oceanogr., 66, 231250, doi:10.1016/j.pocean.2004.03.002, 2005.

Mortlock, R. A. and Froelich, P. N.: A simple method for the rapid determination of biogenic opal in pelagic marine sediments, Deep-Sea Res., 36, 1415-1426, doi:10.1016/01980149(89)90092-7, 1989.

Müller, P. J.: $\mathrm{C} / \mathrm{N}$ ratios in Pacific deep-sea sediments: effect of inorganic ammonium and organic nitrogen compounds sorbed by clays, Geochim. Cosmochim. Ac., 41, 765-776, doi:10.1016/0016-7037(77)90047-3, 1977.

Nieuwenhuize, J., Maas, Y. E. M., and Middelburg, J. J.: Rapid analysis of organic carbon and nitrogen in particulate materials, Mar. Chem., 45, 217-224, doi:10.1016/0304-4203(94)90005-1, 1994.

Ohkouchi, N., Kawamura, K., Kawahata, H., and Taira, A.: Latitudinal distributions of terrestrial biomarkers in the sediments from the Central Pacific, Geochim. Cosmochim. Ac., 61, 1911-1918, doi:10.1016/S0016-7037(97)00040-9, 1997.

Olgun, N., Duggen, S., Andronico, D., Kutterolf, S., Croot, P. L., Giammanco, S., Censi, P., and Randazzo, L.: Possible impacts of volcanic ash emissions of Mount Etna on the primary productivity in the oligotrophic Mediterranean Sea: results from nutrient-release experiments in seawater, Mar. Chem., 152, 32 42, doi:10.1016/j.marchem.2013.04.004, 2013.

Orlic, M., Gacic, M., and Laviolette, P. E.: The currents and circulation of the Adriatic Sea, Oceanol. Acta, 15, 109-124, 1992.
Parinos, C., Gogou, A., Bouloubassi, I., Pedrosa-Pàmies, R., Hatzianestis, I., Sanchez-Vidal, A., Rousakis, G., Velaoras, D., Krokos, G., and Lykousis, V.: Occurrence, sources and transport pathways of natural and anthropogenic hydrocarbons in deep-sea sediments of the eastern Mediterranean Sea, Biogeosciences, 10, 6069-6089, doi:10.5194/bg-10-6069-2013, 2013.

Pedrosa-Pàmies, R., Sanchez-Vidal, A., Calafat, A., Canals, M., and Durán, R.: Impact of storm-induced remobilization on grain size distribution and organic carbon content in sediments from the Blanes Canyon area, NW Mediterranean Sea, Prog. Oceanogr., 118, 122-136, doi:10.1016/j.pocean.2013.07.023, 2013.

Perdue, E. M. and Koprivnjak, J.-F.: Using the $\mathrm{C} / \mathrm{N}$ ratio to estimate terrigenous inputs of organic matter to aquatic environments, Estuar. Coast. Shelf S., 73, 65-72, doi:10.1016/j.ecss.2006.12.021, 2007.

Polymenakou, P. N., Tselepides, A., Stephanou, E. G., and Bertilsson, S.: Carbon speciation and composition of natural microbial communities in polluted and pristine sediments of the Eastern Mediterranean Sea, Mar. Pollut. Bull., 52, 1396-1405, doi:10.1016/j.marpolbul.2006.03.021, 2006.

Psarra, S., Tselepides, A., and Ignatiades, L.: Primary productivity in the oligotrophic Cretan Sea (NE Mediterranean): seasonal and interannual variability, Prog. Oceanogr., 46, 187-204, doi:10.1016/S0079-6611(00)00018-5, 2000.

Rabitti, S., Bianchi, F., Boldrin, A., Daros, L., Socal, G., and Totti, C.: Particulate matter and phytoplankton in the Ionian Sea, Oceanol. Acta, 17, 297-307, 1994.

Rampen, S. W., Willmott, V., Kim, J.-H., Uliana, E., Mollenhauer, G., Schefuß, E., Sinninghe Damsté, J. S., and Schouten, S.: Long chain 1,13- and 1,15-diols as a potential proxy for palaeotemperature reconstruction, Geochim. Cosmochim. Acta, 84, 204-216, doi:10.1016/j.gca.2012.01.024, 2012.

Ratmeyer, V., Balzer, W., Bergametti, G., Chiapello, I., Fischer, G., and Wyputta, U.: Seasonal impact of mineral dust on deepocean particle flux in the eastern subtropical Atlantic Ocean, Mar. Geol., 159, 241-252, doi:10.1016/S0025-3227(98)001972, 1999.

Redfield, A. C., Ketchum, B. H., and Richards, F. A.: The influence of organisms on the composition of sea-water, in: The Sea, edited by: Hill, M. N., Interscience, New York, 26-77, 1963.

Robinson, A. R., Malanotte-Rizzoli, P., Hecht, A., Michelato, A., Roether, W., Theocharis, A., Ünlüata, Ü., Pinardi, N., Artegiani, A., and Bergamasco, A.: General circulation of the Eastern Mediterranean, Earth-Sci. Rev., 32, 285-309, 1992.

Robinson, A. R., Leslie, W. G., Theocharis, A., and Lascaratos, A.: Mediterranean Sea circulation, in: Encyclopedia of Ocean Sciences, Academic Press, 1689-1706, 2001.

Roether, W. and Well, R.: Oxygen consumption in the Eastern Mediterranean, Deep-Sea Res. Pt. I, 48, 1535-1551, doi:10.1016/S0967-0637(00)00102-3, 2001.

Romero, I. C., Schwing, P. T., Brooks, G. R., Larson, R. A., Hastings, D. W., Ellis, G., Goddard, E. A., and Hollander, D. J.: Hydrocarbons in Deep-Sea Sediments following the 2010 Deepwater Horizon Blowout in the Northeast Gulf of Mexico, edited by: Chin, W.-C., PLoS One, 10, e0128371, doi:10.1371/journal.pone.0128371, 2015.

Roussiez, V., Ludwig, W., Monaco, A., Probst, J.-L., Bouloubassi, I., Buscail, R., and Saragoni, G.: Sources and sinks of sediment-bound contaminants in the Gulf of Lions (NW 
Mediterranean Sea): a multi-tracer approach, Cont. Shelf Res., 26, 1843-1857, doi:10.1016/j.csr.2006.04.010, 2006.

Rullkötter, J.: Organic matter: the driving force for early diagenesis, in Marine geochemistry, edited by: Schulz, H. D. and Zabel, M., Springer Berlin Heidelberg, 125-168, 2006.

Rumolo, P., Barra, M., Gherardi, S., Marsella, E., and Sprovieri, M.: Stable isotopes and $\mathrm{C} / \mathrm{N}$ ratios in marine sediments as a tool for discriminating anthropogenic impact., J. Environ. Monitor., 13, 3399-408, doi:10.1039/c1em10568j, 2011.

Rutten, A., de Lange, G.., Ziveri, P., Thomson, J., Van Santvoort, P. J. M., Colley, S., and Corselli, C.: Recent terrestrial and carbonate fluxes in the pelagic eastern Mediterranean; a comparison between sediment trap and surface sediment, Palaeogeogr. Palaeocl., 158, 197-213, doi:10.1016/S00310182(00)00050-X, 2000.

Salihoğlu, İ., Saydam, C., Baştürk, Ö., Yilmaz, K., Göçmen, D., Hatipoglu, E., and Yilmaz, A.: Transport and distribution of nutrients and chlorophyll $a$ by mesoscale eddies in the northeastern Mediterranean, Mar. Chem., 29, 375-390, doi:10.1016/03044203(90)90024-7, 1990.

Sanchez-Vidal, A., Pasqual, C., Kerhervé, P., Calafat, A., Heussner, S., Palanques, a., Durrieu de Madron, X., Canals, M., and Puig, P.: Impact of dense shelf water cascading on the transfer of organic matter to the deep western Mediterranean basin, Geophys. Res. Lett., 35, L05605, doi:10.1029/2007GL032825, 2008.

Schlitzer, R.: Ocean Data View, available at: http://odv.awi.de, 2011.

Schlitzer, R., Roether, W., Oster, H., Junghans, H.-G., Hausmann, M., Johannsen, H., and Michelato, A.: Chlorofluoromethane and oxygen in the Eastern Mediterranean, DeepSea Res., 38, 1531-1551, doi:10.1016/0198-0149(91)90088-W, 1991.

Seiter, K., Hensen, C., Schröter, J., and Zabel, M.: Organic carbon content in surface sediments - defining regional provinces, DeepSea Res. Pt. I, 51, 2001-2026, doi:10.1016/j.dsr.2004.06.014, 2004.

Selvaraj, K., Lee, T. Y., Yang, J. Y. T., Canuel, E. A., Huang, J. C., Dai, M., Liu, J. T., and Kao, S. J.: Stable isotopic and biomarker evidence of terrigenous organic matter export to the deep sea during tropical storms, Mar. Geol., 364, 32-42, doi:10.1016/j.margeo.2015.03.005, 2015.

Siokou-Frangou, I., Gotsis-Skretas, O., Christou, E. D., and Pagou, K.: Plankton characteristics in the Aegean, Ionian and NW Levantine Seas, in: The Eastern Mediterranean as a Laboratory Basin for the Assessment of Contrasting Ecosystems, edited by: Malanotte-Rizzoli, P. and Eremeev, V. N., Kluwer Academic Publisher, Dordrecht Boston London, 465-473, 1999.

Skonieczny, C., Bory, A., Bout-Roumazeilles, V., Abouchami, W., Galer, S. J. G., Crosta, X., Diallo, A., and Ndiaye, T.: A threeyear time series of mineral dust deposits on the West African margin: sedimentological and geochemical signatures and implications for interpretation of marine paleo-dust records, Earth Planet. Sc. Lett., 364, 145-156, doi:10.1016/j.eps1.2012.12.039, 2013.

Statham, P. J. and Hart, V.: Dissolved iron in the Cretan Sea (eastern Mediterranean), Limnol. Oceanogr., 50, 1142-1148, doi:10.4319/lo.2005.50.4.1142, 2005.

Stavrakakis, S., Chronis, G., Tselepides, A., Heussner, S., Monaco, A., and Abassi, A.: Downward fluxes of settling particles in the deep Cretan Sea (NE Mediterranean), Prog. Oceanogr., 46, 217-240, doi:10.1016/S0079-6611(00)00020-3, 2000 .

Stavrakakis, S., Gogou, A., Krasakopoulou, E., Karageorgis, A. P., Kontoyiannis, H., Rousakis, G., Velaoras, D., Perivoliotis, L., Kambouri, G., Stavrakaki, I., and Lykousis, V.: Downward fluxes of sinking particulate matter in the deep Ionian Sea (NESTOR site), eastern Mediterranean: seasonal and interannual variability, Biogeosciences, 10, 7235-7254, doi:10.5194/bg-10-7235-2013, 2013.

Struck, U., Emeis, K.-C., Voß, M., Krom, M. D., and Rau, G. H.: Biological productivity during sapropel S5 formation in the Eastern Mediterranean Sea: evidence from stable isotopes of nitrogen and carbon, Geochim. Cosmochim. Ac., 65, 3249-3266, doi:10.1016/S0016-7037(01)00668-8, 2001.

Taupier-Letage, I.: On the use of thermal images for circulation studies: applications to the Eastern Mediterranean basin, in: Remote Sensing of the European Seas, edited by: Barale, V. and Gade, M., Springer Netherlands, 153-164, 2008.

Tesi, T., Miserocchi, S., Goñi, M. A., Langone, L., Boldrin, A., and Turchetto, M.: Organic matter origin and distribution in suspended particulate materials and surficial sediments from the western Adriatic Sea (Italy), Estuar. Coast. Shelf Sci., 73, 431446, doi:10.1016/j.ecss.2007.02.008, 2007a.

Tesi, T., Miserocchi, S., Goñi, M. A., and Langone, L.: Source, transport and fate of terrestrial organic carbon on the western Mediterranean Sea, Gulf of Lions, France, Mar. Chem., 105, 101-117, doi:10.1016/j.marchem.2007.01.005, 2007b.

Tesi, T., Langone, L., Goñi, M. A., Turchetto, M., Miserocchi, S., and Boldrin, A.: Source and composition of organic matter in the Bari canyon (Italy): Dense water cascading versus particulate export from the upper ocean, Deep Sea Res. Pt. I, 55, 813-831, doi:10.1016/j.dsr.2008.03.007, 2008 .

Theocharis, A., Georgopoulos, D., Lascaratos, A., and Nittis, K.: Water masses and circulation in the central region of the Eastern Mediterranean: Eastern Ionian, South Aegean and Northwest Levantine, 1986-1987, Deep-Sea Res. Pt. II, 40, 1121-1142, 1993.

Theocharis, A., Balopoulos, E., Kioroglou, S., Kontoyiannis, H., and Iona, A.: A synthesis of the circulation and hydrography of the South Aegean Sea and the Straits of the Cretan Arc (March 1994-January 1995), Prog. Oceanogr., 44, 469-509, doi:10.1016/S0079-6611(99)00041-5, 1999.

Theodosi, C., Parinos, C., Gogou, A., Kokotos, A., Stavrakakis, S., Lykousis, V., Hatzianestis, J., and Mihalopoulos, N.: Downward fluxes of elemental carbon, metals and polycyclic aromatic hydrocarbons in settling particles from the deep Ionian Sea (NESTOR site), Eastern Mediterranean, Biogeosciences, 10, 4449-4464, doi:10.5194/bg-10-4449-2013, 2013.

Thingstad, T. F., Krom, M. D., Mantoura, R. F. C., Flaten, G. A. F., Groom, S., Herut, B., Kress, N., Law, C. S., Pasternak, A., Pitta, P., Psarra, S., Rassoulzadegan, F., Tanaka, T., Tselepides, A., Wassmann, P., Woodward, E. M. S., Riser, C. W., Zodiatis, G., and Zohary, T.: Nature of phosphorus limitation in the ultraoligotrophic eastern Mediterranean, Science, 309, 1068-1071, doi:10.1126/science.1112632, 2005.

Triantaphyllou, M. V.: Coccolithophore export production and response to seasonal surface water variability in the olig- 
otrophic Cretan Sea (NE Mediterranean), Micropaleontology, 50(Suppl_1), 127-144, doi:10.2113/50.Suppl_1.127, 2004.

Tsapakis, M. and Stephanou, E. G.: Occurrence of gaseous and particulate polycyclic aromatic hydrocarbons in the urban atmosphere: study of sources and ambient temperature effect on the gas/particle concentration and distribution, Environ. Pollut., 133, 147-156, doi:10.1016/j.envpol.2004.05.012, 2005.

Turchetto, M., Boldrin, A., Langone, L., Miserocchi, S., Tesi, T., and Foglini, F.: Particle transport in the Bari Canyon (southern Adriatic Sea), Mar. Geol., 246, 231-247, doi:10.1016/j.margeo.2007.02.007, 2007.

UNEP/MAP/MEDPOL: Sub-Regional Assessment of the Status of Marine and Coastal Ecosystems and of Pressures to the Marine and Coastal Environment Eastern Mediterranean Sea UNEP(DEPI)/MEDWG.350/Inf.4, Barcelona, 37-38, 2010.

Ursella, L., Kovačević, V., and Gačić, M.: Tidal variability of the motion in the Strait of Otranto, Ocean Sci., 10, 49-67, doi:10.5194/os-10-49-2014, 2014.

Van Santvoort, P. J. M., de Lange, G. J., Thomson, J., Cussen, H., Wilson, T. R. S., Krom, M. D., and Ströhle, K.: Active post-depositional oxidation of the most recent sapropel (S1) in sediments of the eastern Mediterranean Sea, Geochim. Cosmochim. Ac., 60, 4007-4024, doi:10.1016/S00167037(96)00253-0, 1996.

Van Santvoort, P. J. M., De Lange, G. J., Thomson, J., Colley, S., Meysman, F. J. R., and Slomp, C. P.: Oxidation and origin of organic matter in surficial eastern Mediterranean hemipelagic sediments, Aquat. Geochem., 8, 153-175, 2002.

Volkman, J. K.: A review of sterol markers for marine and terrigenous organic matter, Org. Geochem., 9, 83-99, doi:10.1016/0146-6380(86)90089-6, 1986.
Volkman, J. K.: Lipid markers for marine organic matter, in: Marine Organic Matter: Biomarkers, Isotopes and DNA, edited by: Volkman, J. K., Springer Verlag, Berlin, 27-70, 2006.

Volkman, J. K., Kearney, P., and Jeffrey, S. W.: A new source of 4methyl sterols and $5 \alpha(\mathrm{H})$-stanols in sediments: prymnesiophyte microalgae of the genus Pavlova, Org. Geochem., 15, 489-497, doi:10.1016/0146-6380(90)90094-G, 1990.

Volkman, J. K., Barrett, S. M., and Blackburn, S. I.: Eustigmatophyte microalgae are potential sources of C29 sterols, C22C28 n-alcohols and C28-C32 n-alkyl diols in freshwater environments, Org. Geochem., 30, 307-318, doi:10.1016/S01466380(99)00009-1, 1999.

Wang, Z., Fingas, M., and Page, D. S.: Oil spill identification, J. Chromatogr. A, 843, 369-411, doi:10.1016/S00219673(99)00120-X, 1999.

Weldeab, S., Emeis, K.-C., Hemleben, C., and Siebel, W.: Provenance of lithogenic surface sediments and pathways of riverine suspended matter in the Eastern Mediterranean Sea: evidence from $143 \mathrm{Nd} / 144 \mathrm{Nd}$ and $87 \mathrm{Sr} / 86 \mathrm{Sr}$ ratios, Chem. Geol., 186, 139-149, doi:10.1016/S0009-2541(01)00415-6, 2002.

Ziveri, P., Rutten, A., de Lange, G.., Thomson, J., and Corselli, C.: Present-day coccolith fluxes recorded in central eastern Mediterranean sediment traps and surface sediments, Palaeogeogr. Palaeocl., 158, 175-195, doi:10.1016/S0031-0182(00)00049-3, 2000.

Zoccolotti, L. and Salusti, E.: Observations of a vein of very dense marine water in the southern Adriatic Sea, Cont. Shelf Res., 7, 535-551, doi:10.1016/0278-4343(87)90020-3, 1987. 